\title{
Quantifying Soldier Shooting Performance of the M4 Carbine with and without a Vertical Grip
}

by Samson V Ortega Jr, William H Harper, and Frank Morelli 


\section{NOTICES}

\section{Disclaimers}

The findings in this report are not to be construed as an official Department of the Army position unless so designated by other authorized documents.

Citation of manufacturer's or trade names does not constitute an official endorsement or approval of the use thereof.

Destroy this report when it is no longer needed. Do not return it to the originator. 


\section{Army Research Laboratory}

Aberdeen Proving Ground, MD 21005-5425

\section{Quantifying Soldier Shooting Performance of the M4 Carbine with and without a Vertical Grip}

Samson V Ortega Jr, William H Harper, and Frank Morelli

Human Research and Engineering Directorate, ARL 


\section{REPORT DOCUMENTATION PAGE}

Form Approved OMB No. 0704-0188

Public reporting burden for this collection of information is estimated to average 1 hour per response, including the time for reviewing instructions, searching existing data sources, gathering and maintaining the data needed, and completing and reviewing the collection information. Send comments regarding this burden estimate or any other aspect of this collection of information, including suggestions for reducing the burden, to Department of Defense, Washington Headquarters Services, Directorate for Information Operations and Reports (0704-0188), 1215 Jefferson Davis Highway, Suite 1204, Arlington, VA 22202-4302. Respondents should be aware that notwithstanding any other provision of law, no person shall be subject to any penalty for failing to comply with a collection of information if it does not display a currently valid OMB control number.

PLEASE DO NOT RETURN YOUR FORM TO THE ABOVE ADDRESS.

\begin{tabular}{|c|c|c|}
\hline $\begin{array}{l}\text { 1. REPORT DATE (DD-MM-YYYY) } \\
\text { January } 2015\end{array}$ & $\begin{array}{l}\text { 2. REPORT TYPE } \\
\text { Final }\end{array}$ & $\begin{array}{l}\text { 3. DATES COVERED (From - To) } \\
\text { June 2013-August } 2013\end{array}$ \\
\hline \multirow{4}{*}{\multicolumn{2}{|c|}{$\begin{array}{l}\text { 4. TITLE AND SUBTITLE } \\
\text { Quantifying Soldier Shooting Performance of the M4 Carb } \\
\text { Vertical Grip }\end{array}$}} & 5a. CONTRACT NUMBER \\
\hline & & \\
\hline & & 5b. GRANT NUMBER \\
\hline & & 5c. PROGRAM ELEMENT NUMBER \\
\hline \multirow{3}{*}{\multicolumn{2}{|c|}{$\begin{array}{l}\text { 6. AUTHOR(S) } \\
\text { Samson V Ortega Jr, William H Harper, and Frank Morelli }\end{array}$}} & 5d. PROJECT NUMBER \\
\hline & & 5e. TASK NUMBER \\
\hline & & 5f. WORK UNIT NUMBER \\
\hline \multicolumn{2}{|c|}{$\begin{array}{l}\text { 7. PERFORMING ORGANIZATION NAME(S) AND ADDRESS(ES) } \\
\text { US Army Research Laboratory } \\
\text { ATTN: RDRL-HRS-B } \\
\text { Aberdeen Proving Ground, MD } 21005-5425\end{array}$} & $\begin{array}{l}\text { 8. PERFORMING ORGANIZATION } \\
\text { REPORT NUMBER } \\
\text { ARL-TR-7173 }\end{array}$ \\
\hline \multirow{2}{*}{\multicolumn{2}{|c|}{ 9. SPONSORING/MONITORING AGENCY NAME(S) AND ADDRESS(ES) }} & 10. SPONSOR/MONITOR'S ACRONYM(S) \\
\hline & & $\begin{array}{l}\text { 11. SPONSOR/MONITOR'S REPORT } \\
\text { NUMBER(S) }\end{array}$ \\
\hline
\end{tabular}

\section{DISTRIBUTIONIAVAILABILITY STATEMENT}

Approved for public release; distribution is unlimited.

\section{SUPPLEMENTARY NOTES}

\section{ABSTRACT}

The Human Research and Engineering Directorate's Dismounted Warrior Branch conducted a live-fire research study where subjects were asked to engage targets at various ranges using an M4 carbine with and without a vertical grip. The objectives of the study were to quantify subjects' shooting performance of the M4 carbine with and without a vertical grip and to determine subjects' subjective responses on their perceived shooting performance and preferences while shooting the M4 carbine. Of the 18 subjects, 6 were US Army Soldiers and 12 were officers from the local Special Response Team (a local police force at Aberdeen Proving Ground). All 18 subjects fired both weapon conditions in the reflexive posture at 10-, 25-, and 50-m targets and aimed posture at 50-, 100-, and 150-m targets. For the reflexive posture, all subjects conducted 3 training trials with 24 rounds per trial, firing at 24 targets exposed for $3.5 \mathrm{~s}$ and later 3 record trials with 24 rounds per trial firing at 24 targets. A similar scenario was conducted in the aimed posture only using 6-s target exposure times. Shooting performance data were collated by the range computer and analyzed for significant differences between weapon configurations. The results of this study showed that for the mean number of targets hit, mean radial error (distance from the point of aim on the E-silhouette target), mean time to shoot, and mean time to hit the target, there were no significant differences in any of the weapon configurations (M4 with and without a vertical grip) in either the reflexive or aimed firing postures, suggesting that perhaps the use of a vertical grip should be left to the discretion of each user.

\section{SUBJECT TERMS}

vertical grip, M4 carbine, shooting performance, hit rate, control, stability

\begin{tabular}{|l|l|l|c|c|l|}
\hline \multicolumn{2}{|l|}{ 16. SECURITY CLASSIFICATION OF: } & $\begin{array}{l}\text { 17. LIMITATION } \\
\text { OF ABSTRACT }\end{array}$ & $\begin{array}{l}\text { 18. NUMBER } \\
\text { OF PAGES }\end{array}$ & $\begin{array}{l}\text { 19a. NAME OF RESPONSIBLE PERSON } \\
\text { Samson V Ortega Jr }\end{array}$ \\
\cline { 1 - 2 } $\begin{array}{l}\text { a. REPORT } \\
\text { Unclassified }\end{array}$ & $\begin{array}{l}\text { b. ABSTRACT } \\
\text { Unclassified }\end{array}$ & $\begin{array}{l}\text { c. THIS PAGE } \\
\text { Unclassified }\end{array}$ & UU & 50 & $\begin{array}{l}\text { 19b. TELEPHONE NUMBER (Include area code) } \\
410-278-5990\end{array}$ \\
\hline
\end{tabular}




\section{Contents}

List of Figures $\quad$ v

List of Tables

Acknowledgments

1. Introduction and Background $\quad 1$

2. Subjects $\quad 1$

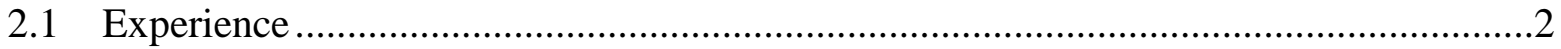

2.2 Demographics and Anthropometrics ..............................................................

2.3 Voluntary Participation ...................................................................................

3. Test Items $\quad 5$

4. Shooting Performance Evaluation 6

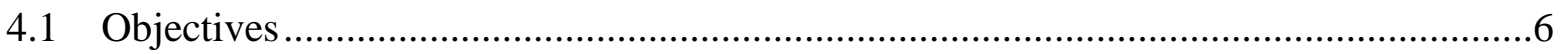

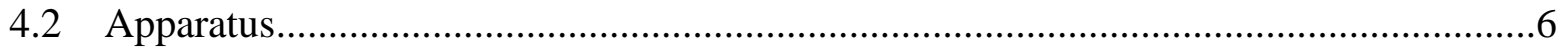

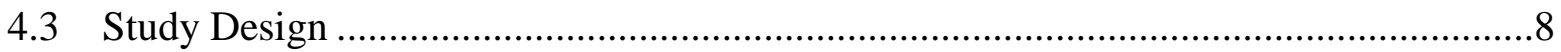

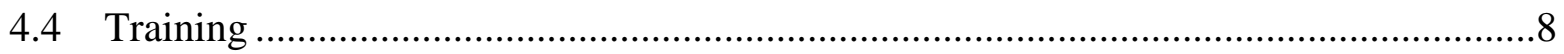

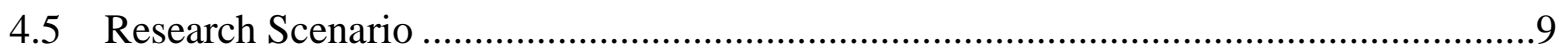

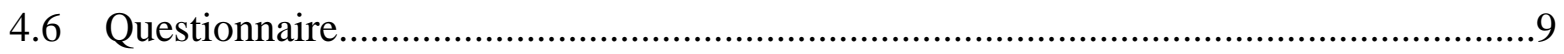

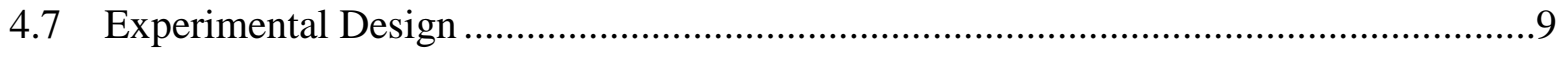

4.7.1 Reflexive Firing................................................................................

4.7.2 Aimed Firing .....................................................................................

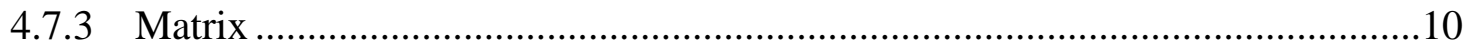

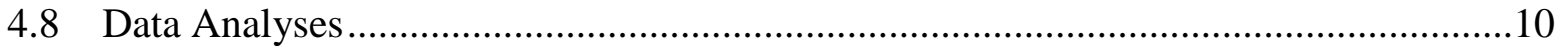

5. Results $\quad 11$

5.1 Reflexive Firing at Close Targets......................................................................11

5.1.1 Mean Target Hit Rate ...........................................................................11

5.1.2 Mean Radial Error .......................................................................................11

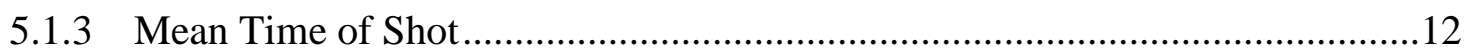


5.1.4 Mean Time of Hit ..................................................................................12

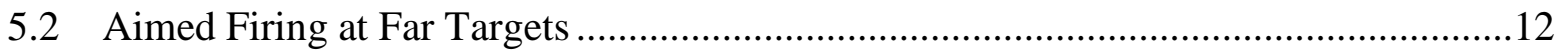

5.2.1 Mean Target Hit Rate ......................................................................... 12

5.2.2 Mean Radial Error ......................................................................................13

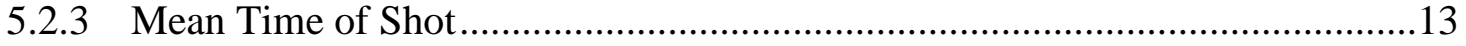

5.2.4 Mean Time of Hit ......................................................................................13

$\begin{array}{lr}\text { 6. Discussion } & 20\end{array}$

$\begin{array}{ll}\text { 7. Conclusion } & 22\end{array}$

8. Recommendations $\quad 22$

9. References $\quad 25$

Appendix A. Demographic and Anthropometric Data Sheets 27

Appendix B. Informed Consent Form

$\begin{array}{ll}\text { Appendix C. Posttest Questionnaire } & 37\end{array}$

$\begin{array}{ll}\text { Distribution List } & 39\end{array}$ 


\section{List of Figures}

Fig. 1 M4 carbine with vertical grip with an M68 CCO........................................................5

Fig. 2 Standard M4 Carbine without vertical grip with an M68 CCO .....................................6

Fig. 3 ARL HRED M-Range Shooting Performance Research Facility ...................................7

Fig. 4 Olive-drab E-type silhouette targets at M-Range ......................................................7

Fig. 5 Soldier shooting the M4 carbine without the vertical grip .........................................14

Fig. 6 Soldier shooting the M4 carbine with the vertical grip ............................................15

Fig. 7 Examples of bracing, rather than securely grasping, the weapon using the forward vertical grip 


\section{List of Tables}

Table 1 Summary of subjects' demographic information...................................................2

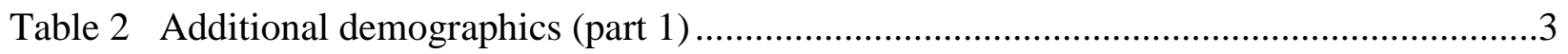

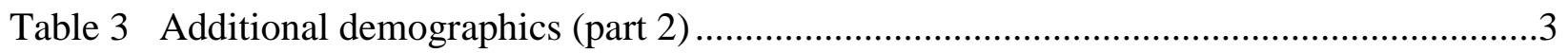

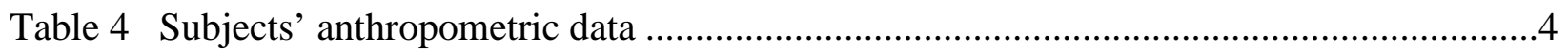

Table 5 Counterbalanced order of weapon configuration for each test participant.....................10

Table 6 Mean target hit rate (close targets) for reflexive firing.............................................11

Table 7 Mean radial error in inches (close targets) for reflexive firing...................................12

Table 8 Mean time of shot (close targets) for reflexive firing ..............................................12

Table 9 Mean time of hit (close targets) for reflexive firing .................................................12

Table 10 Mean target hit rate (far targets) for aimed firing..................................................13

Table 11 Mean radial error in inches (far targets) for aimed firing .........................................13

Table 12 Mean time of shot (far targets) for aimed firing .....................................................13

Table 13 Mean time of hit (far targets) for aimed firing.....................................................14

Table 14 Means and standard deviations of responses to questionnaires ................................15

Table 15 Summary of subjects' comments (direct quotes) from shooting the M4 carbine

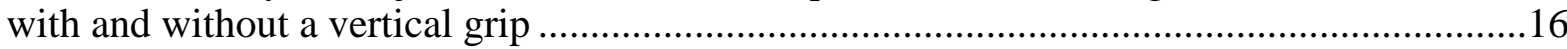




\section{Acknowledgments}

We wish to thank the Soldiers from the US Army Research Laboratory (ARL) and the Soldiers from the US Army Test and Evaluation Command, and the Department of Defense Special Response Team officers who volunteered to participate in this study.

We also wish to thank the following ARL personnel from the Human Research and Engineering Directorate, Soldier Performance Division, Dismounted Warrior Branch:

- Paul Shorter, Thomas Fry, Douglas Struve, and Caleb Gordon for providing range support to collect the live-fire shooting data at M-Range.

- Patty Burcham for data reduction of the responses to the demographic and anthropometric questionnaires, and for providing range support during the live-fire trials at M-Range.

- Ed Baur for programming the range computer for the target scenarios, running the range computer, and gathering and reducing the shooting performance data for statistical analyses.

In addition, we'd like to thank Justin Dawson from the Firepower Directorate, Small Arms Caliber Field Team, US Army Aberdeen Test Center, for providing various sizes of the Improved Outer Tactical Vest for the shooters' use, and the vertical grips and plastic forward rail covers for use on the M4 carbines. 
INTENTIONALLY LEFT BLANK. 


\section{Introduction and Background}

Special Operations Forces (SOF) personnel have the latitude of obtaining needed materiel to accomplish their missions without having to go through as cumbersome an acquisition process, relative to US Army general purpose forces. One of the materiel items obtained by SOF was the Special Operations Peculiar Modification to the M4 Carbine (SOPMOD M4). The SOPMOD M4 carbine is a modular weapon system that may be modified with various attachments designed to satisfy the specific mission needs for the SOF operator. One of these available modifications is the installation of a vertical grip. As a result of this modification to the M4 carbine (use of the vertical grip), other units in the Army have likewise modified their standard-issue weapons with the installation of the vertical grip.

Anecdotal evidence among Army users of the vertical grip on the M4 carbine indicates that it affords better control and increased accuracy as compared to firing a standard M4 carbine without the vertical grip. Users claim that the vertical grip allows for the weapon to be pulled tighter toward the shoulder for better stability and consequently better accuracy.

Army programs, such as Land Warrior, have considered using the vertical grip as a position on which to mount controls for auxiliary items, fire control, or computer systems. Without information regarding the effect on shooting performance with and without a vertical grip, it is difficult to understand the impact, if any, on shooting performance.

A literature search was conducted to determine if any previous studies addressed the shooting performance of any weapon system with and without a vertical grip. There were no studies found that addressed the topic in question; therefore, it is not known if the use of a vertical grip impacts control and weapon accuracy.

Because the vertical grip is designed to afford improved control and stability when handling and aiming the weapon, it was predicted that firing with the vertical grip would result in greater accuracy during reflexive firing at close-range targets or during aimed standing unsupported firing at long-range targets.

\section{Subjects}

A total of 18 Soldiers were requested for this study. However, only 6 were available to participate and subsequently volunteered for this research effort. Given the dearth of additional available Soldiers local to Aberdeen Proving Ground (APG), locally stationed Department of Defense Special Response Team (SRT) personnel volunteered to participate after approval was granted by the US Army Research Laboratory (ARL) Institutional Review Board. 
Twelve personnel from the SRT subsequently volunteered for the study. SRT personnel are a local police special weapon and tactics element stationed at APG consisting of prior-service military personnel who normally use various small-arms weapon systems when conducting their training and official duties.

\subsection{Experience}

No specialized experience was required for participation in this study. It was desirable to have subjects with shooting experience but not necessary. Subjects were not dismissed from this study because of firing experience level since all subjects acted as their own control. However, subjects were required to have qualified with their weapon within a year of the conduct of this study.

\subsection{Demographics and Anthropometrics}

Demographic and anthropometric data were collected to characterize the experience level and specific body measurements of the subjects in this study. Demographic data were provided by the test participants using the Demographic Data Form (Appendix A).

These anthropometric measures were then converted to percentile equivalents. These data were collated to compare the subjects to the US Army population (Gordon et al. 1989). A sample demographic and anthropometric data sheet is shown in Appendix A. Table 1 contains summaries of subjects' demographic information, while Tables 2 and 3 contain additional demographic information. Table 4 contains the subjects' anthropometry data with the percentile equivalent.

Table 1 Summary of subjects’ demographic information

\begin{tabular}{|c|c|c|c|c|c|c|c|c|c|}
\hline $\begin{array}{c}\text { Subject } \\
\text { No. }\end{array}$ & Age & Sex & Rank & \begin{tabular}{|c|} 
Time in \\
$\begin{array}{c}\text { Service (years, } \\
\text { months) }\end{array}$
\end{tabular} & $\begin{array}{l}\text { Time in } \\
\text { Service, or } \\
\text { in SRT }\end{array}$ & $\begin{array}{c}\text { Primary } \\
\text { MOS }\end{array}$ & $\begin{array}{c}\text { Secondary or } \\
\text { Prior Service } \\
\text { MOS }\end{array}$ & $\begin{array}{c}\text { Time in } \\
\text { Current } \\
\text { MOS/SRT }\end{array}$ & $\begin{array}{l}\text { Time in } \\
\text { Military }\end{array}$ \\
\hline 1 & 32 & $\mathrm{M}$ & SFC & $12 \mathrm{y}, 11 \mathrm{mo}$ & $\ldots$ & $13 \mathrm{~F}$ & $\ldots$ & $12 \mathrm{y}, 11 \mathrm{mo}$ & $\ldots$ \\
\hline 2 & 44 & $\mathrm{M}$ & SSG & $17 \mathrm{y}$ & $\ldots$ & $13 \mathrm{~T}$ & $68 \mathrm{~K}$ & $10 \mathrm{y}$ & $\ldots$ \\
\hline 3 & 35 & $M$ & SSG & $17 \mathrm{y}$ & $\ldots$ & $35 \mathrm{~L}$ & 19D & $2 y$ & $\ldots$ \\
\hline 4 & 34 & $M$ & 1LT & $15 \mathrm{y}, 3 \mathrm{mo}$ & $\ldots$ & $90 \mathrm{~A}$ & 11B & $6 y$ & $\ldots$ \\
\hline 5 & 30 & $\mathrm{M}$ & CPT & $7 y$ & $\ldots$ & $14 \mathrm{~A}$ & N/A & $7 y$ & $\ldots$ \\
\hline 6 & 39 & $\mathrm{M}$ & CPT & $20 \mathrm{y}, 6 \mathrm{mo}$ & $\ldots$ & $90 \mathrm{~A}$ & $91 \mathrm{~A}$ & $3 y$ & $\ldots$ \\
\hline 7 & 31 & $\mathrm{M}$ & SRT & $7 y$ & $8 y$ & SRT & $31 \mathrm{~B}$ & $8 y$ & $7 y$ \\
\hline 8 & 33 & $\mathrm{M}$ & OFC & $5 y$ & $4 \mathrm{y}$ & SRT & 6073 USMC & $4 y$ & $5 y$ \\
\hline 9 & 33 & $M$ & SRT & $11 \mathrm{y}, 3 \mathrm{mo}$ & $5 y$ & SRT & $31 \mathrm{~B}$ & $5 y$ & $11 \mathrm{y}$ \\
\hline 10 & 30 & $\mathrm{M}$ & SRT & $7 \mathrm{y}, 7 \mathrm{mo}$ & $6 y$ & SRT & N/A & $6 \mathrm{y}$ & $7 \mathrm{y}$ \\
\hline 11 & 28 & $\mathrm{M}$ & SRT & $4 \mathrm{y}$ & $4 y$ & SRT & N/A & $4 \mathrm{y}$ & $4 y$ \\
\hline 12 & 48 & $\mathrm{M}$ & SRT & $10 \mathrm{y}, 1 \mathrm{mo}$ & $9 y$ & SRT & 2111 USMC & $9 y$ & $20 y$ \\
\hline 13 & 30 & $\mathrm{M}$ & SRT & $5 \mathrm{y}$ & $3 y$ & SRT & $31 \mathrm{~B}$ & $3 y$ & $\ldots$ \\
\hline 14 & 31 & $\mathrm{M}$ & $\begin{array}{l}\text { SRT } \\
\end{array}$ & $8 \mathrm{y}, 8 \mathrm{mo}$ & $8 \mathrm{y}$ & SRT & $31 \mathrm{~B} / 31 \mathrm{E}$ & 8 y 6 mo & $8 \mathrm{y}$ \\
\hline 15 & 30 & $M$ & SRT & $4 \mathrm{y}, 0 \mathrm{mo}$ & $\ldots$ & SRT & N/A & $\ldots$ & $\ldots$ \\
\hline 16 & 36 & $\mathrm{M}$ & SRT & $5 y$ & $\ldots$ & SRT & 2531, USMC & $5 y$ & $\ldots$ \\
\hline 17 & 33 & $\mathrm{M}$ & SRT & $14 \mathrm{y}$ & $14 \mathrm{y}$ & SRT & $31 \mathrm{~B}$ & $9 y$ & $\ldots$ \\
\hline 18 & 38 & $\mathrm{M}$ & SRT & $11 \mathrm{y}$ & N/A & SRT & $95 B$ & $16 \mathrm{y}$ & $\ldots$ \\
\hline
\end{tabular}

Notes: SRT = Special Response Team, and MOS = military occupational specialty. 
Table 2 Additional demographics (part 1)

\begin{tabular}{|c|c|c|c|c|c|c|}
\hline $\begin{array}{c}\text { Subject } \\
\text { No. }\end{array}$ & $\begin{array}{c}\text { Last Time } \\
\text { Qualified } \\
\text { Rifle/Carbine } \\
\text { (month, year) }\end{array}$ & Weapon & $\begin{array}{l}\text { Current Level of } \\
\text { Qualification as } \\
\text { Rifleman }\end{array}$ & $\begin{array}{c}\text { Shooter } \\
\text { Handedness }\end{array}$ & $\begin{array}{l}\text { Eye to Aim } \\
\text { Weapon }\end{array}$ & $\begin{array}{c}\text { Corrective } \\
\text { Glasses }\end{array}$ \\
\hline 1 & 2, 2012 & M4 & Expert & Right & Right & Yes \\
\hline 2 & 10, 2012 & M4 & Sharpshooter & Left & Left & No \\
\hline 3 & 9,2012 & M4 & Expert & Right & Right & Yes \\
\hline 4 & 5,2013 & M4 & Sharpshooter & Right & Right & Yes \\
\hline 5 & 2,2013 & M4 & Sharpshooter & Right & Right & No \\
\hline 6 & 4, 2013 & M4 & Sharpshooter & Right & Right & No \\
\hline 7 & 5,2013 & M4 & Expert & Right & Right & Yes \\
\hline 8 & 5, 2013 & M4 & Expert & Right & Right & No \\
\hline 9 & 5,2013 & M4 & Expert & Right & Right & Yes \\
\hline 10 & 5,2013 & M4 & Expert & Right & Right & Yes \\
\hline 11 & 4,2013 & M4 & Expert & Right & Right & No \\
\hline 12 & 5,2013 & M4 & Expert & Right & Right & Yes \\
\hline 13 & 7,2013 & M4 & Expert & Right & Right & No \\
\hline 14 & 7,2013 & M4 & Expert & Right & Right & No \\
\hline 15 & 7, 2013 & M4 & Expert & Left & Left & No \\
\hline 16 & 7, 2013 & M4 & Expert & Left & Left & No \\
\hline 17 & 10, 2012 & M4 & Expert & Right & Right & No \\
\hline 18 & 7,2013 & M4 & Expert & Right & Right & No \\
\hline
\end{tabular}

Table 3 Additional demographics (part 2)

\begin{tabular}{|c|c|c|c|c|c|c|c|}
\hline $\begin{array}{c}\text { Subject } \\
\text { No. }\end{array}$ & $\begin{array}{c}\text { Difficulty } \\
\text { Seeing in } \\
\text { Daytime? }\end{array}$ & $\begin{array}{c}\text { Used Optical or } \\
\text { Thermal Sights? }\end{array}$ & $\begin{array}{c}\text { If Yes, Device } \\
\text { Type }\end{array}$ & $\begin{array}{c}\text { Exp. with } \\
\text { ACOG }\end{array}$ & $\begin{array}{c}\text { Exp. } \\
\text { with } \\
\text { M68 }\end{array}$ & $\begin{array}{c}\text { Exp. } \\
\text { with } \\
\text { M145 } \\
\text { MGO }\end{array}$ & $\begin{array}{c}\text { Exp. with } \\
\text { AN/PAS 13 } \\
\text { TWS }\end{array}$ \\
\hline 1 & No & Yes & M68, ACOG & Yes & Yes & No & No \\
\hline 2 & No & No & $\ldots$ & Yes & Yes & No & No \\
\hline 3 & No & Yes & $\ldots$ & Yes & Yes & No & Yes \\
\hline 4 & No & Yes & $\begin{array}{c}\text { M68, ACOG, } \\
\text { sniper scope }\end{array}$ & Yes & Yes & No & No \\
\hline 5 & No & Yes & M2, M240 & Yes & Yes & Yes & Yes \\
\hline 6 & No & Yes & CCO, ACOG & Yes & No & No & Yes \\
\hline 7 & No & Yes & $\begin{array}{c}\text { ACOG, M68, } \\
\text { EOTech }\end{array}$ & Yes & Yes & No & Yes \\
\hline 8 & No & Yes & $\ldots$ & Yes & Yes & No & Yes \\
\hline
\end{tabular}


Table 3 Additional demographics (part 2) (continued)

\begin{tabular}{|c|c|c|c|c|c|c|c|}
\hline $\begin{array}{c}\text { Subject } \\
\text { No. }\end{array}$ & $\begin{array}{c}\text { Difficulty } \\
\text { Seeing in } \\
\text { Daytime? }\end{array}$ & $\begin{array}{c}\text { Used Optical or } \\
\text { Thermal Sights? }\end{array}$ & $\begin{array}{c}\text { If Yes, Device } \\
\text { Type }\end{array}$ & $\begin{array}{c}\text { Exp. with } \\
\text { ACOG }\end{array}$ & $\begin{array}{c}\text { Exp. } \\
\text { with } \\
\text { M68 }\end{array}$ & $\begin{array}{c}\text { Exp. } \\
\text { with } \\
\text { M145 } \\
\text { MGO }\end{array}$ & $\begin{array}{c}\text { Exp. with } \\
\text { AN/PAS 13 } \\
\text { TWS }\end{array}$ \\
\hline 9 & No & Yes & $\begin{array}{c}\text { ACOG, EOTech, } \\
\text { Mark IV sniper } \\
\text { scope }\end{array}$ & Yes & Yes & No & No \\
\hline 10 & No & Yes & $\begin{array}{c}\text { EOTech, ACOG, } \\
\text { CCO }\end{array}$ & Yes & Yes & No & No \\
\hline 11 & No & No & $\ldots$ & Yes & No & No & No \\
\hline 12 & No & Yes & $\ldots$ & Yes & No & No & No \\
\hline 13 & No & Yes & $\begin{array}{c}\text { Leupold Rifle } \\
\text { scope }\end{array}$ & Yes & No & No & No \\
\hline 14 & No & Yes & $\begin{array}{c}\text { EOTech, ACOG } \\
\text { w/magnifiers, M68 }\end{array}$ & Yes & Yes & No & No \\
\hline 15 & No & Yes & $\ldots$ & Yes & No & No & No \\
\hline 16 & No & Yes & $\begin{array}{c}\text { Halo Grange, } \\
\text { standard scopes, } \\
\text { ACOG }\end{array}$ & Yes & Yes & No & No \\
\hline 17 & No & No & $\ldots$ & Yes & Yes & No & No \\
\hline 18 & No & Yes & $\begin{array}{c}\text { EOTech/ACOG/ } \\
\text { M68 }\end{array}$ & Yes & Yes & No & Yes \\
\hline
\end{tabular}

Notes: ACOG = Advanced Combat Optic Gunsight, $\mathrm{CCO}$ = close-combat optic, MGO = Machine Gun Optic, AN PAS 13 TWS $=$ Thermal Weapon Sight.

Table 4 Subjects' anthropometric data

\begin{tabular}{|c|c|c|c|c|}
\hline \multirow{2}{*}{$\begin{array}{c}\text { Subject } \\
\text { No. }\end{array}$} & \multicolumn{2}{|c|}{ Stature } & \multicolumn{2}{|c|}{ Weight } \\
\hline & $\mathbf{c m}$ & Percentile & kg & Percentile \\
\hline 1 & 170.2 & $21 \mathrm{st}$ & 81.5 & 63rd \\
\hline 2 & 182.9 & 86th & 82.5 & 67th \\
\hline 3 & 175.6 & 51st & 94.7 & 92nd \\
\hline 4 & 185.3 & 94th & 101.1 & 97th \\
\hline 5 & 175.4 & 50th & 86.3 & 77th \\
\hline 6 & 178.8 & 70th & 94.0 & 91st \\
\hline 7 & 177.4 & 61st & 105.1 & 99th \\
\hline 8 & 168.9 & 16th & 75.0 & 41st \\
\hline 9 & 171.4 & 29th & 85.9 & 76th \\
\hline 10 & 185.4 & 95th & 97.3 & 94th \\
\hline 11 & 179.0 & 70th & 94.3 & 91st \\
\hline 12 & 169.3 & 18th & 76.6 & 46th \\
\hline 13 & 176.2 & 54th & 81.6 & 64th \\
\hline 14 & 181.2 & 80th & 94.8 & 92th \\
\hline 15 & 173.7 & 40th & 89.4 & 84th \\
\hline 16 & 160.7 & $1 \mathrm{st}$ & 85.7 & 76th \\
\hline 17 & 169.7 & 19th & 81.2 & 62nd \\
\hline 18 & 183.2 & 87th & 108.8 & $>99$ th \\
\hline
\end{tabular}




\subsection{Voluntary Participation}

The subjects were given an orientation on the purpose of the study and their participation. They were briefed on the objectives and procedures as well as on the apparatus. They were also told how the results would be used and the benefits the military could expect from this investigation. Any questions the subjects asked regarding the study were answered. In addition, the Volunteer Agreement Affidavit was explained and its contents verbally presented. The subjects were then given the Informed Consent Form (Appendix B) to read and sign if they decided to volunteer.

To ensure the voluntary nature of participation, copies of the consent form were provided to all participating subjects. The subjects were given an opportunity to review the experiment objectives and to have any of their questions answered by the investigators. The subjects were also informed that if they chose not to participate, they could convey that choice privately to the principal investigator. Subjects were also informed that they could withdraw from participation at any time. None of the subjects ultimately decided to withdraw from participation prior to completion of experimental trials.

\section{Test Items}

The M4/M4A1 5.56-mm Carbine is a lightweight, gas-operated, air-cooled, magazine-fed, selective rate, shoulder-fired weapon with a collapsible stock. Equipped with a shorter barrel (14.5 inches), collapsible stock, and accessory rails, it provides Soldiers operating in close quarters with improved handling relative to long-barreled weapon systems, and the capability to rapidly and accurately engage targets at extended ranges, day or night.

Figure 1 shows an M4 carbine with a rail-mounted forward vertical grip, and Fig. 2 shows the standard M4 carbine without forward rail-mounted attachments. In both images, the M4 is fitted with an M68 close-combat optic (CCO).

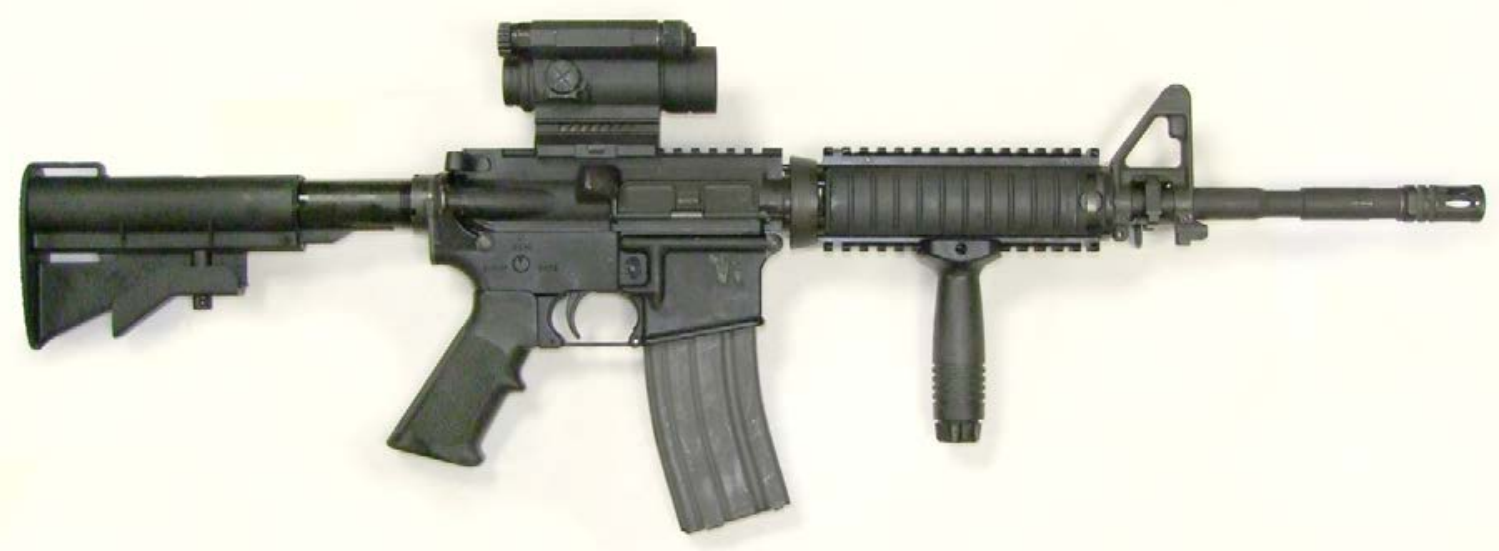

Fig. 1 M4 carbine with vertical grip with an M68 CCO 


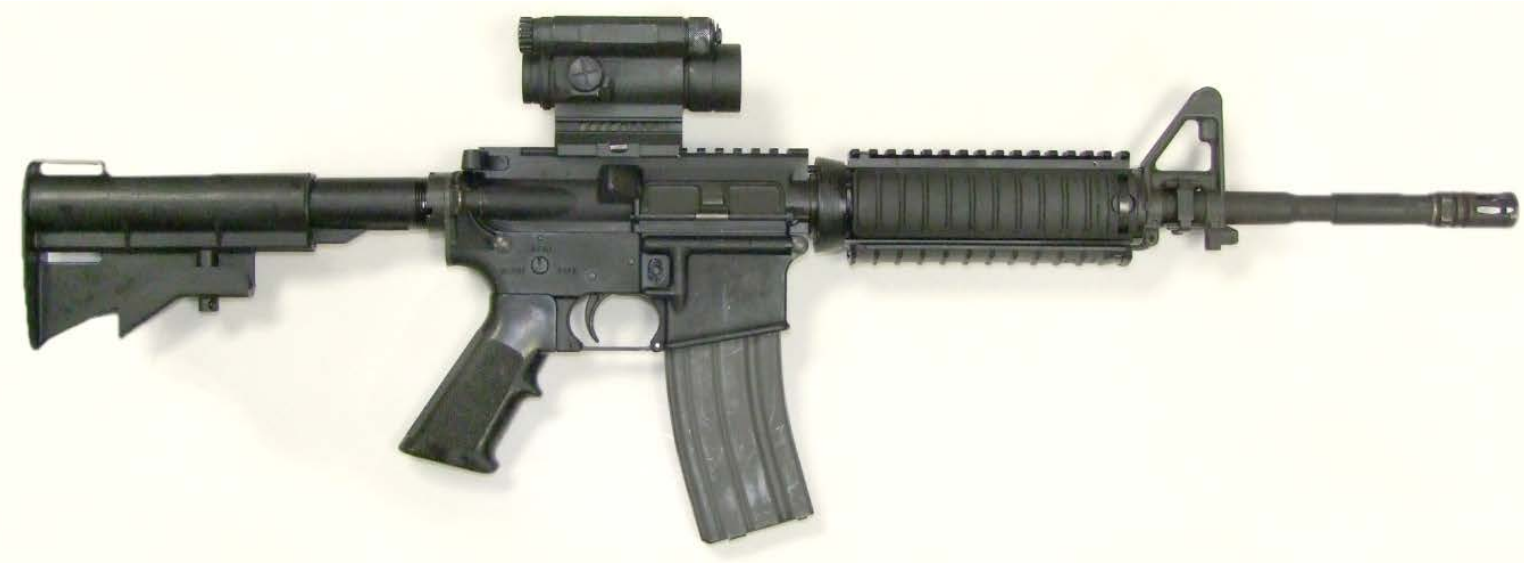

Fig. 2 Standard M4 Carbine without vertical grip with an M68 CCO

\section{Shooting Performance Evaluation}

\subsection{Objectives}

The objectives of the evaluation were as follows:

- To determine if shooting performance is affected by the use of a vertical grip.

- To determine subjective responses with respect to perceived shooting performance and preferences while shooting the M4 carbine with and without a vertical grip.

\subsection{Apparatus}

M-Range is a live-fire shooting range used to evaluate shooting performance of small-arms systems (.50 caliber or smaller). It consists of 4 parallel firing lanes with target positions from 10 to $550 \mathrm{~m}$ on the 2 left lanes and targets from 10 to $1,000 \mathrm{~m}$ on the 2 right lanes. Figure 3 provides an aerial photograph of the Human Research and Engineering Directorate's (HRED's) M-Range. Target control is automated using customized computer algorithms that enable the operator to program target presentation scenarios and record live-fire marksmanship data. The target positions can support a variety of target types (e.g., E-type silhouettes [Fig. 4], 3-D IVAN targets), which are presented and retracted using pneumatically operated arms. Target control parameters include target sequence, range, presentation time, and duration, and may be varied to accommodate a broad selection of experimental scenarios. Accuracy and timing data are recorded using shot microphones placed at the shooter's position and behind each target. The supersonic projectile of each shot, whether firing in semiautomatic or full automatic mode, generates a shock wave that is detected by the microphones. Shock wave timing is used to triangulate shot location, accurate to within $5 \mathrm{~mm}$, and is expressed as an $x-y$ coordinate relative to the target plane. Shock waves from shots that miss the target by up to approximately 12 inches surrounding the target are also captured. 


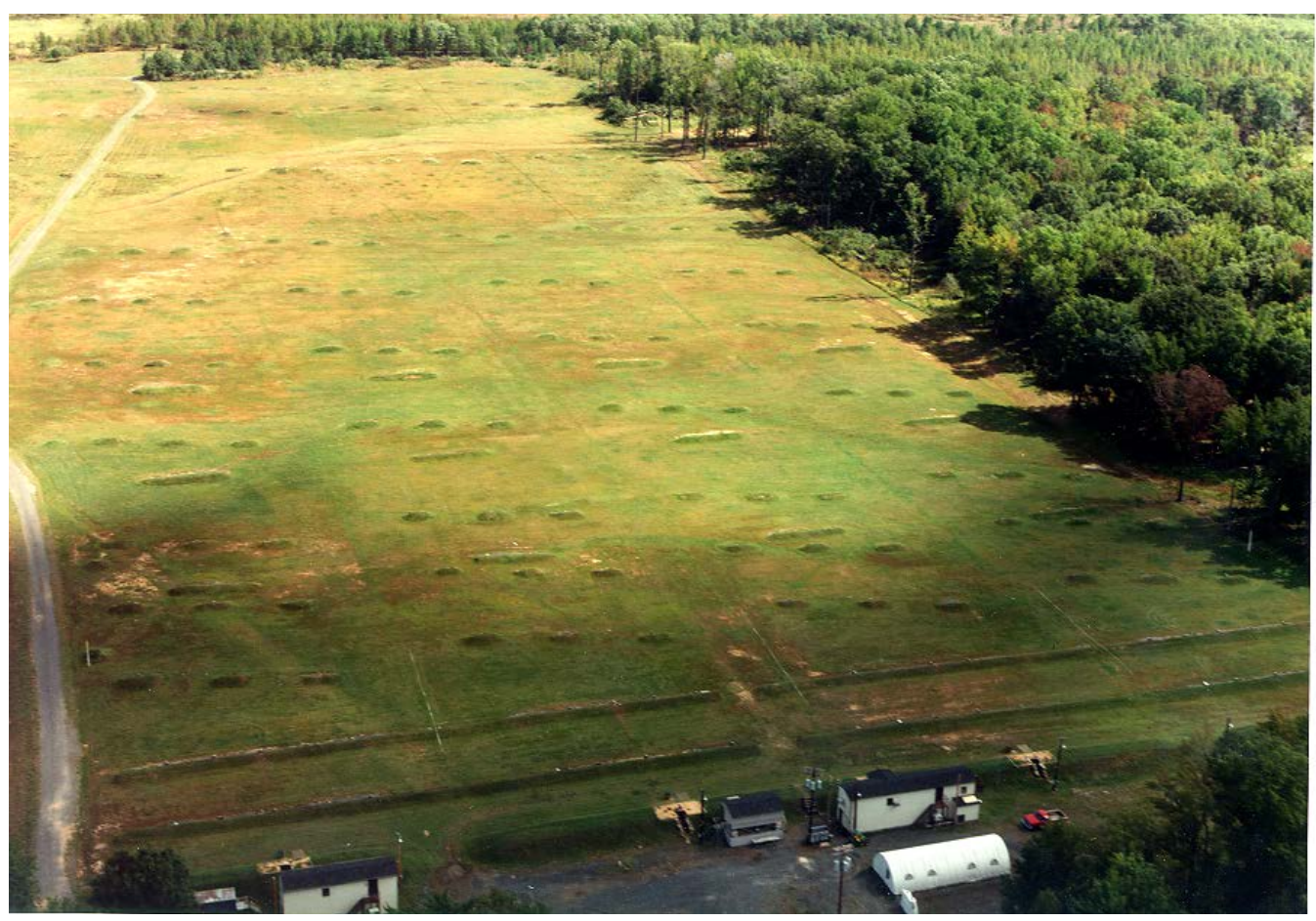

Fig. 3 ARL HRED M-Range Shooting Performance Research Facility

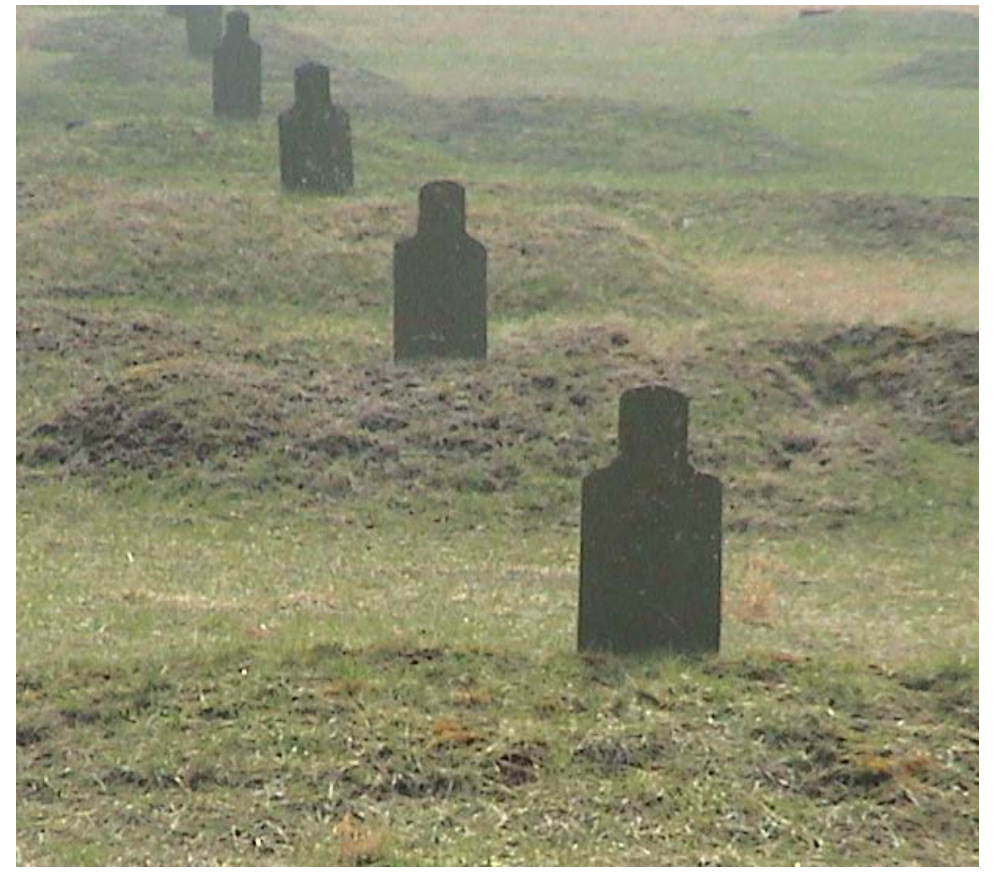

Fig. 4 Olive-drab E-type silhouette targets at M-Range 


\subsection{Study Design}

This study quantified each subject's shooting performance using the M4 carbine with and without the use of the vertical grip. All subjects fired both weapon configurations during the course of this research. In addition, subjects fired the weapon in a reflexive mode at close targets while standing unsupported and fired the weapon in an aimed mode at far targets while standing unsupported. They completed questionnaires that asked about the experience of shooting using both weapon configurations. All firing was conducted during daylight hours.

\subsection{Training}

Subjects fired in both experimental conditions over the course of a single work day. To account for practice and order effects, the order in which the subjects fired the weapons was counterbalanced. Subjects began the day by being issued the first weapon condition they would be firing that day. After the first weapon condition was fired, the weapon was modified for the second weapon condition for that day (i.e., installed or removed the vertical grip). Subjects then zeroed the M68 reflex sight that was mounted on the weapon according to standard US Army zeroing procedures (US Army 2003). Once zeroed, subjects completed 3 training trials for the reflexive firing portion of the study. During the reflexive firing training, targets appeared at ranges of 10, 25, and $50 \mathrm{~m}$. Subjects were in the standing unsupported firing position and started with the weapon in the low ready position. When the target was exposed, subjects engaged the target with 2 aimed shots. A total of 24 shots were fired for each trial for a total of 72 shots for each condition. The aimpoint was a marked center of mass location on the target. Subjects were told to aim at the marked center of mass location of the target, were scored on the proximity of their hits relative to that aimpoint, and were timed on how long it took them to fire each round. The target exposure time was $3.5 \mathrm{~s}$. Each subject completed 3 training trials. Each training trial consisted of 12 targets (i.e., 4 targets at each range).

Once the subject completed the 3 reflexive firing training trials with the assigned weapon condition, the subject moved on to the reflexive fire-testing portion of the study. A break was given between the training and testing trials, which allowed for rest prior to performing the test trials. The testing portion was conducted exactly as the training had been conducted. Subjects completed 3 test trials in the reflexive firing scenario.

Following the reflexive firing training, subjects were trained in the aimed fire at far targets while in the standing unsupported portion of the study. Subjects completed 3 training trials in the standing unsupported position with 12 targets (i.e., 4 targets at each range) appearing at 50, 100, and $150 \mathrm{~m}$ with an exposure time of $6 \mathrm{~s}$. When the target was exposed, the subject engaged the target with 2 aimed shots. A total of 24 shots were fired for each trial for a total of 72 shots for each condition. The aimpoint was a marked center of mass location on the target. As described for training, subjects were told to aim at the marked center of mass location of the target, were scored on the proximity of their hits relative to that aimpoint, and were timed on how long it took them to fire each round. 


\subsection{Research Scenario}

After the training trials were completed for each weapon condition, subjects completed the test experimental trials: reflexive firing at close-range targets and aimed firing at long-range targets at the prescribed distances. These trials were performed under exactly the same procedures as the training trials. Three test trials were conducted each for the reflexive firing at close targets and aimed firing at far targets, both in the standing unsupported firing position. When the subject was done with the first weapon condition, the weapon was modified for the second weapon condition; training was then conducted, and then the test experimental trials were conducted.

When the test participants completed firing in both the reflexive firing and aimed firing, they completed the post-firing questionnaire (Appendix C).

\subsection{Questionnaire}

Once the test participants completed a specific weapon condition, they were asked to complete the shooting performance questionnaire (Appendix $\mathrm{C}$ ).

\subsection{Experimental Design}

\subsubsection{Reflexive Firing}

\subsubsection{Independent Variables}

The independent variables were the weapon configurations (M4 carbine with and without a vertical grip), ranges (10, 25, and $50 \mathrm{~m}$ ), and target exposure time (3.5 s).

\subsubsection{Dependent Variables}

The dependent variables were number of targets hit, radial error of the projectile impacts on the target, time of shot, and time to hit.

\subsubsection{Aimed Firing}

\subsubsection{Independent Variables}

The independent variables were the weapon configurations (M4 carbine with and without a vertical grip), ranges (50,100, and $150 \mathrm{~m})$, and target exposure time (6.0 s).

\subsubsection{Dependent Variables}

The dependent variables were number of targets hit, radial error of the projectile impacts on the target, time of shot, and time to hit. 


\subsubsection{Matrix}

The counterbalanced presentation order in Table 5 was used to determine the order of the weapon condition for each test participant.

For each subject firing a specific weapon configuration, the automated target system recorded the number of shots fired, number of targets hit, time to first shot, time to second shot, and $\mathrm{X}$ and $\mathrm{Y}$ coordinates of projectile impacts and misses surrounding the E-silhouette target.

Table 5 Counterbalanced order of weapon configuration for each test participant

\begin{tabular}{|c|c|c|}
\hline \multirow{2}{*}{ Participant No. } & \multicolumn{2}{|c|}{ Weapon Condition } \\
\cline { 2 - 3 } & 1 & 2 \\
\hline 1 & A & B \\
\hline 2 & B & A \\
\hline 3 & A & B \\
\hline 4 & B & A \\
\hline 5 & A & B \\
\hline 6 & B & A \\
\hline 7 & A & B \\
\hline 8 & B & A \\
\hline 9 & A & B \\
\hline 10 & B & A \\
\hline 11 & A & B \\
\hline 12 & B & A \\
\hline 13 & A & B \\
\hline 14 & B & A \\
\hline 15 & A & B \\
\hline 16 & B & A \\
\hline 17 & A & B \\
\hline 18 & B & A \\
\hline
\end{tabular}

$\mathrm{A}=\mathrm{M} 4$ carbine without vertical grip

$\mathrm{B}=\mathrm{M} 4$ carbine with vertical grip

\subsection{Data Analyses}

Separate analysis of variance (ANOVA) was conducted on the collated shooting performance data for the reflexive and aimed firing. A within-subjects repeated-measures ANOVA was conducted on the dependent variables (number of targets hit, radial error of the projectile impacts on the target, time to shot, and time to hit the target) using the independent variables of weapon configuration, range, and target exposure time. These analyses included a check for compound symmetry. If the assumption for compound symmetry was violated, then the conservative Greenhouse-Geisser correction for the degrees of freedom was used. The level of significance for these analyses was 0.05 . 
For the responses to the questionnaire data, an ANOVA was used to quantify perceived differences across weapon configurations.

For the questionnaire data, user feedback was tabulated, and preferences and alternative methodologies were reported.

\section{Results}

If the fired projectile was beyond $1 \mathrm{ft}$ outside the E-silhouette target edge, the M-Range computer scoring system did not record that missed shot, so that was treated as missing data since there was no way to properly fill in that data void. This method will underestimate the reported means of radial error since the shots with the most error were not included in the calculations.

The statistical analyses were divided by the type of shooting that was done. Separate statistical analyses were done for the reflexive firing condition at targets from 10 to $50 \mathrm{~m}$ (close targets) and for the aimed firing for targets from 50 to $150 \mathrm{~m}$ (far targets).

\subsection{Reflexive Firing at Close Targets}

\subsubsection{Mean Target Hit Rate}

An ANOVA was used to determine significant differences between weapon configurations for the mean target hit rate. The ANOVA showed that there was no significant difference $\left(\mathrm{F}_{(1,17)}=\right.$ $1.114, \mathrm{p}=0.306$ ) between weapon configurations. Table 6 shows the mean target hit rate by weapon configuration.

Table 6 Mean target hit rate (close targets) for reflexive firing

\begin{tabular}{|l|c|c|}
\hline \multicolumn{1}{|c|}{ Weapon Configuration } & Mean Target Hit Rate & $\begin{array}{c}\text { Standard } \\
\text { Deviation }\end{array}$ \\
\hline M4 carbine without vertical grip & 0.98 & 0.148 \\
\hline M4 carbine with vertical grip & 0.97 & 0.172 \\
\hline
\end{tabular}

\subsubsection{Mean Radial Error}

An ANOVA was used to determine significant differences between weapon configurations for the mean radial error. The ANOVA showed that there was no significant difference $\left(\mathrm{F}_{(1,17)}=\right.$ 0.121 , $p=0.732$ ) between weapon configurations. Table 7 shows mean radial error by weapon configuration. 
Table 7 Mean radial error in inches (close targets) for reflexive firing

\begin{tabular}{|l|c|c|}
\hline \multicolumn{1}{|c|}{ Weapon Configuration } & $\begin{array}{c}\text { Mean Radial Error } \\
\text { (in) }\end{array}$ & $\begin{array}{c}\text { Standard } \\
\text { Deviation }\end{array}$ \\
\hline M4 carbine without vertical grip & 7.21 & 2.591 \\
\hline M4 carbine with vertical grip & 7.24 & 2.487 \\
\hline
\end{tabular}

\subsubsection{Mean Time of Shot}

An ANOVA was used to determine significant differences between weapon configurations for the mean time of shot. The ANOVA showed that there was no significant difference $\left(\mathrm{F}_{(1,17)}=\right.$ $0.698, p=0.415$ ) between weapon configurations. Table 8 shows mean time of shot by weapon configuration.

Table 8 Mean time of shot (close targets) for reflexive firing

\begin{tabular}{|l|c|c|}
\hline \multicolumn{1}{|c|}{ Weapon Configuration } & $\begin{array}{c}\text { Mean Time of Shot } \\
\text { (s) }\end{array}$ & $\begin{array}{c}\text { Standard } \\
\text { Deviation }\end{array}$ \\
\hline M4 carbine without vertical grip & 2.42 & 0.582 \\
\hline M4 carbine with vertical grip & 2.39 & 0.547 \\
\hline
\end{tabular}

\subsubsection{Mean Time of Hit}

An ANOVA was used to determine significant differences between weapon configurations for the mean time of hit. The ANOVA showed that there was no significant difference $\left(\mathrm{F}_{(1,17)}=\right.$ $0.700, p=0.414$ ) between weapon configurations. Table 9 shows mean time of hit by weapon configuration.

Table 9 Mean time of hit (close targets) for reflexive firing

\begin{tabular}{|l|c|c|}
\hline \multicolumn{1}{|c|}{ Weapon Configuration } & $\begin{array}{c}\text { Mean Time of Hit } \\
\text { (s) }\end{array}$ & $\begin{array}{c}\text { Standard } \\
\text { Deviation }\end{array}$ \\
\hline M4 carbine without vertical grip & 2.45 & 0.588 \\
\hline M4 carbine with vertical grip & 2.42 & 0.553 \\
\hline
\end{tabular}

\subsection{Aimed Firing at Far Targets}

\subsubsection{Mean Target Hit Rate}

An ANOVA was used to determine significant differences between weapon configurations for the mean target hit rate. The ANOVA showed that there was no significant difference $\left(\mathrm{F}_{(1,17)}=\right.$ $0.488, \mathrm{p}=0.494$ ) between weapon configurations. Table 10 shows the mean target hit rate by weapon configuration. 
Table 10 Mean target hit rate (far targets) for aimed firing

\begin{tabular}{|l|c|c|}
\hline \multicolumn{1}{|c|}{ Weapon Configuration } & Mean Target Hit Rate & $\begin{array}{c}\text { Standard } \\
\text { Deviation }\end{array}$ \\
\hline M4 carbine without vertical grip & 0.71 & 0.456 \\
\hline M4 carbine with vertical grip & 0.70 & 0.460 \\
\hline
\end{tabular}

\subsubsection{Mean Radial Error}

An ANOVA was used to determine significant differences between weapon configurations for the mean radial error. The ANOVA showed that there was no significant difference $\left(\mathrm{F}_{(1,17)}=\right.$ 3.842, $\mathrm{p}=0.060$ ) between weapon configurations. Table 11 shows mean radial error by weapon configuration.

Table 11 Mean radial error in inches (far targets) for aimed firing

\begin{tabular}{|l|c|c|}
\hline \multicolumn{1}{|c|}{ Weapon Configuration } & $\begin{array}{c}\text { Mean Radial Error } \\
\text { (in) }\end{array}$ & $\begin{array}{c}\text { Standard } \\
\text { Deviation }\end{array}$ \\
\hline M4 carbine without vertical grip & 6.97 & 3.329 \\
\hline M4 carbine with vertical grip & 7.15 & 3.353 \\
\hline
\end{tabular}

\subsubsection{Mean Time of Shot}

An ANOVA was used to determine significant differences between weapon configurations for the mean time of shot. The ANOVA showed that there was no significant difference $\left(\mathrm{F}_{(1,17)}=\right.$ $0.067, \mathrm{p}=0.798$ ) between weapon configurations. Table 12 shows mean time of shot by weapon configuration.

Table 12 Mean time of shot (far targets) for aimed firing

\begin{tabular}{|l|c|c|}
\hline \multicolumn{1}{|c|}{ Weapon Configuration } & $\begin{array}{c}\text { Mean Time of Shot } \\
\text { (s) }\end{array}$ & $\begin{array}{c}\text { Standard } \\
\text { Deviation }\end{array}$ \\
\hline M4 carbine without vertical grip & 3.32 & 1.028 \\
\hline M4 carbine with vertical grip & 3.31 & 1.024 \\
\hline
\end{tabular}

\subsubsection{Mean Time of Hit}

An ANOVA was used to determine significant differences between weapon configurations for the mean time of hit. The ANOVA showed that there was no significant difference $\left(F_{(1,17)}=0.0\right.$, $\mathrm{p}=0.801$ ) between weapon configurations. Table 13 shows mean time of hit by weapon configuration. 
Table 13 Mean time of hit (far targets) for aimed firing

\begin{tabular}{|l|c|c|}
\hline \multicolumn{1}{|c|}{ Weapon Configuration } & $\begin{array}{c}\text { Mean Time of Hit } \\
\text { (s) }\end{array}$ & $\begin{array}{c}\text { Standard } \\
\text { Deviation }\end{array}$ \\
\hline M4 carbine without vertical grip & 3.43 & 1.042 \\
\hline M4 carbine with vertical grip & 3.42 & 1.040 \\
\hline
\end{tabular}

Figures 5 and 6 show a Soldier shooting the M4 carbine without the vertical grip and with a vertical grip, respectively.

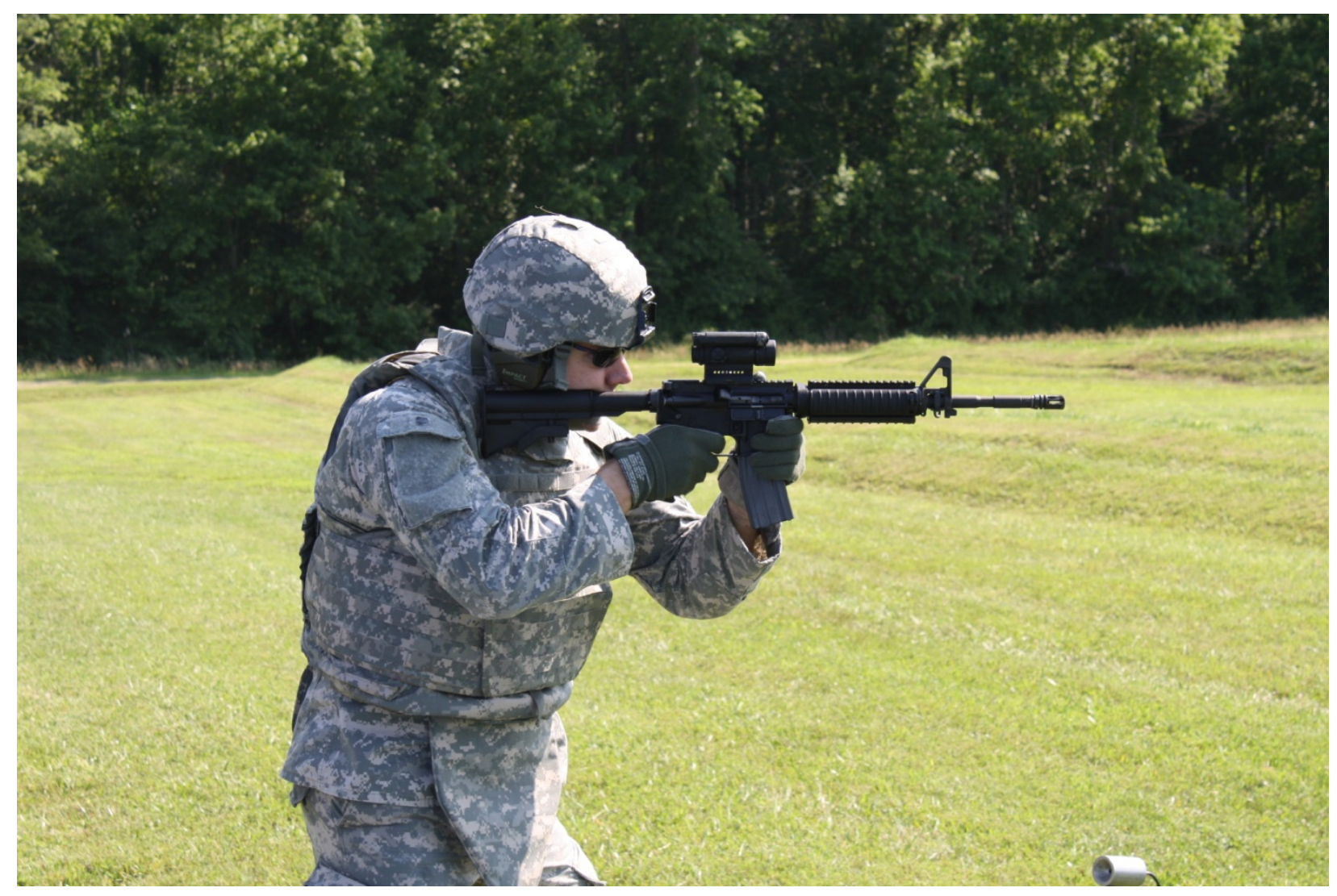

Fig. 5 Soldier shooting the M4 carbine without the vertical grip 


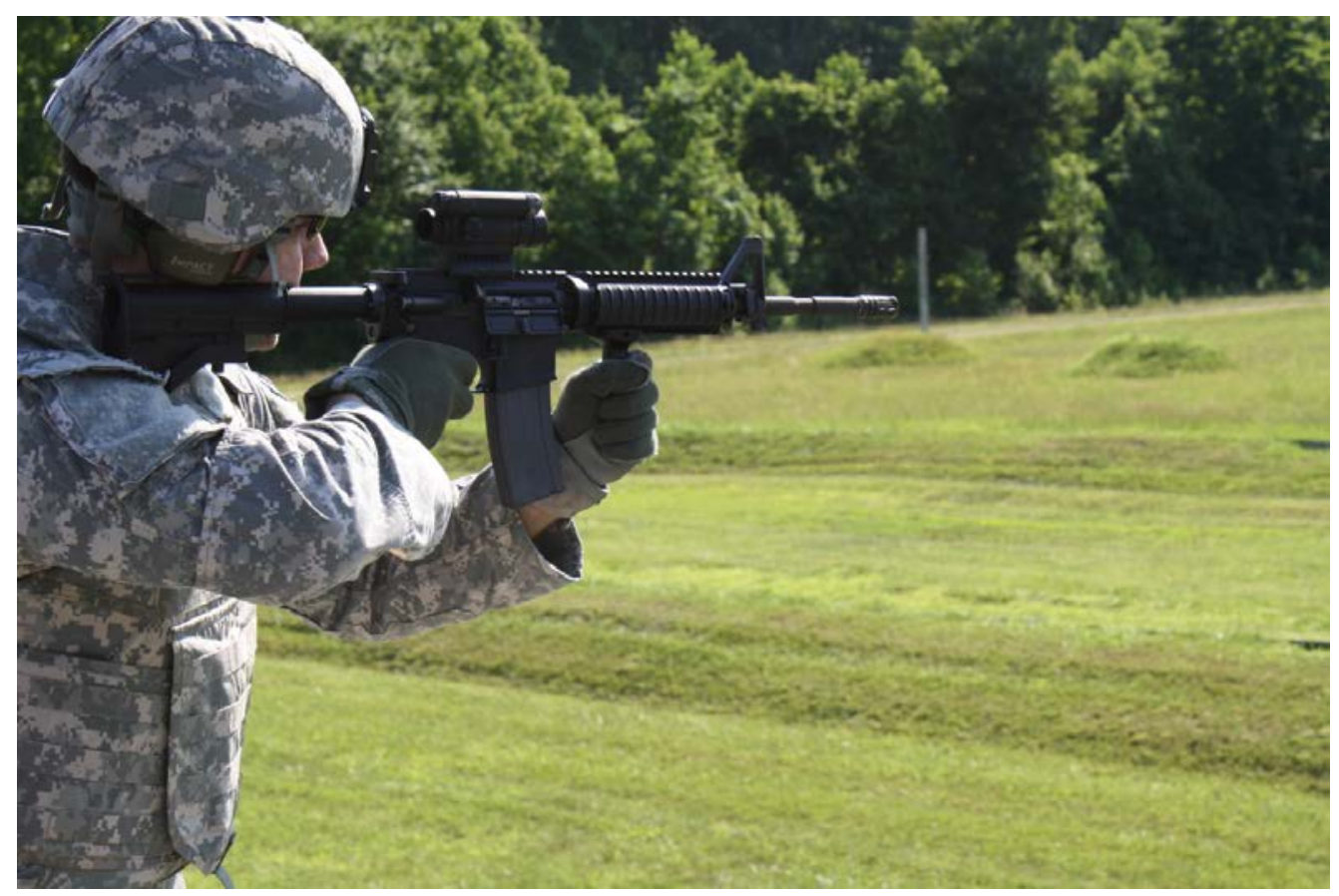

Fig. 6 Soldier shooting the M4 carbine with the vertical grip

Table 14 shows the means of the responses to the questionnaires that the subjects completed.

Table 14 Means and standard deviations of responses to questionnaires

\begin{tabular}{|l|c|c|c|c|}
\hline \multirow{2}{*}{ Characteristics Rated } & \multicolumn{2}{c|}{$\begin{array}{c}\text { M4 Carbine without } \\
\text { Vertical Grip }\end{array}$} & $\begin{array}{c}\text { M4 Carbine with Vertical } \\
\text { Grip }\end{array}$ \\
\cline { 2 - 5 } & Mean & $\begin{array}{c}\text { Standard } \\
\text { Deviation }\end{array}$ & Mean & $\begin{array}{c}\text { Standard } \\
\text { Deviation }\end{array}$ \\
\cline { 2 - 5 } & 3.67 & 0.840 & $\mathbf{4 . 1 7}$ & 0.707 \\
\hline 1. Ease of holding weapon unsupported & 3.56 & 0.984 & 3.94 & 0.725 \\
\hline 2. Ease of holding weapon steady & 3.67 & 1.085 & 4.11 & 0.900 \\
\hline 3. Ease of pulling weapon to shoulder & 3.89 & 0.900 & 4.06 & 0.725 \\
\hline 4. Ease of slewing to target & 4.72 & 0.575 & 4.61 & 0.608 \\
\hline 5. Ease of operating safety lever & 4.06 & 0.938 & 4.22 & 0.732 \\
\hline 6. Ease of obtaining a good sight picture & 3.61 & 0.850 & 4.06 & 0.725 \\
\hline 7. Ease of maintaining a good sight picture & 3.94 & 0.873 & 4.11 & 1.023 \\
\hline 8. Ease of bringing weapon up to cheek & 3.72 & 1.074 & 3.94 & 1.110 \\
\hline 9. Ease of holding cheek to stock weld & $\mathbf{4 . 1 7}$ & 0.618 & $\mathbf{4 . 5 0}$ & 0.786 \\
\hline 10. Ease of scanning for targets & 3.83 & 0.707 & $\mathbf{4 . 2 9}$ & 0.772 \\
\hline 11. Ease of assuming a good firing position & 3.61 & 0.850 & $\mathbf{4 . 0 0}$ & 0.594 \\
\hline 12. Ease of obtaining an accurate first shot & 3.83 & 0.786 & 4.17 & 0.707 \\
\hline 13. Ease of shooting at stationary targets & 4.50 & 0.707 & 4.50 & 0.707 \\
\hline 14. Ease of loading a magazine & 3.89 & 0.832 & 4.22 & 0.732 \\
\hline 15. Weight of weapon & 4.00 & 0.686 & 4.33 & 0.686 \\
\hline 16. Balance of weapon & 3.78 & 0.732 & 4.00 & 0.686 \\
\hline 17. Weapon stability during firing & 3.00 & 0.767 & 3.28 & 0.826 \\
\hline 18. Fatigue induced by using this weapon & & & \\
\hline Note: Bold & & & & \\
\hline
\end{tabular}

Note: Bold, italicized font indicates a significant difference at the 0.05 level using an ANOVA. 
Table 15 is a summary of the subjects’ comments from their experience during the live firing of the M4 carbine with and without a vertical grip.

Table 15 Summary of subjects’ comments (direct quotes) from shooting the M4 carbine with and without a vertical grip

\begin{tabular}{|c|c|}
\hline \multirow[b]{2}{*}{$\begin{array}{l}\text { Subject } \\
\text { No. }\end{array}$} & M4 Carbine without Vertical Grip \\
\hline & $\begin{array}{l}\text { Do you feel that the use of the weapon configuration you just experienced is acceptable for an } \\
\text { assault weapon? Why? }\end{array}$ \\
\hline 1 & Yes, it is easy to bring up to the firing position and to slew to target to set a good aimpoint \\
\hline 2 & Yes, because it is lighter to hold \\
\hline 3 & Yes, very basic configuration without too many other items (i.e. laser or IR light) \\
\hline 4 & $\begin{array}{l}\text { Yes, I felt more in control since I was able to apply forward force from pistol grip and backwards } \\
\text { pull against magazine well. This allowed me to seat the weapon better on my shoulder and obtain a } \\
\text { good cheek weld. }\end{array}$ \\
\hline 5 & Yes, it is capable of performing to the level required for the duration required. \\
\hline 6 & Yes, and it's most likely because this is the way I fired the weapon for the past 20 years. \\
\hline 7 & Yes, because of its size. \\
\hline 8 & Yes, it is personal preference to either use or not use a forward grip. \\
\hline 9 & $\begin{array}{l}\text { Yes, with the M4. It was easy to transition from target to target. When taking my time, it was easy } \\
\text { to acquire a good sight picture. My "support" hand did start to become fatigued half way through } \\
\text { the exercise though. }\end{array}$ \\
\hline 10 & Yes, it allows you to place hands where you want. \\
\hline 11 & Yes, the weapon was very manageable and easy to fire in this configuration. \\
\hline 12 & $\begin{array}{l}\text { I believe the configuration used would be acceptable for an assault weapon because it is quick, } \\
\text { natural, and comfortable. However, I can only say this because over the last three years, I've been } \\
\text { using an M4 with an M203 attachment without the vertical grip. }\end{array}$ \\
\hline 13 & $\begin{array}{l}\text { Yes, even though shooting mechanics declined with continued shooting, still able to make quality } \\
\text { shots, although uncomfortably. }\end{array}$ \\
\hline 14 & $\begin{array}{l}\text { Yes, if taught properly on how to hold the weapon system such as holding further out with your } \\
\text { support hand. I hold my support hand as far out as possible with my thumb over the top. }\end{array}$ \\
\hline 15 & $\begin{array}{l}\text { Yes, I personally like the configuration. If there was any way to make the weapon a little lighter } \\
\text { that would be great. }\end{array}$ \\
\hline 16 & $\begin{array}{l}\text { Yes, still lightweight but the heat from the barrel was almost unbearable after } 80 \text { rounds on my } \\
\text { hand on the hand guards. }\end{array}$ \\
\hline 17 & Yes, this particular weapon is easy to operate and easy to maintain. \\
\hline 18 & Yes. Just not as comfortable and stable as with the fore grip. \\
\hline
\end{tabular}


Table 15 Summary of subjects’ comments (direct quotes) from shooting the M4 carbine with and without a vertical grip (continued)

\begin{tabular}{|c|c|}
\hline \multirow{2}{*}{$\begin{array}{l}\text { Subject } \\
\text { No. }\end{array}$} & M4 Carbine with Vertical Grip \\
\hline & $\begin{array}{l}\text { Do you feel that the use of the weapon configuration you just experienced is acceptable for an } \\
\text { assault weapon? Why? }\end{array}$ \\
\hline 1 & $\begin{array}{l}\text { Yes, was easy far more to maintain a steady aim. I have my own personal grip for a M4 and have } \\
\text { been using it for } 7 \text { years. }\end{array}$ \\
\hline 2 & Yes, because the hand grip helps to steady the weapon. \\
\hline 3 & Yes, same configuration I am (was) used to in Iraq. \\
\hline 4 & $\begin{array}{l}\text { Yes, it gave me the impression that it helped me have more natural control of weapon. The forward } \\
\text { grip assisted in using my front hand to aim. "Point and shoot" was easier. }\end{array}$ \\
\hline 5 & $\begin{array}{l}\text { Yes, even if you want to remove the hand grip, you can easily (do so) on the fly. For instance, if you } \\
\text { wanted to be in the prone supported. }\end{array}$ \\
\hline 6 & $\begin{array}{l}\text { Somewhat. I normally hold the weapon with my non-firing hand on the magazine well, so using the } \\
\text { pistol grip didn’t require a large adjustment for me. }\end{array}$ \\
\hline 7 & Yes, I was able to keep a better stable platform. \\
\hline 8 & $\begin{array}{l}\text { Yes, the forward grip does help shouldering the weapon and remaining tight in the shoulder. It is } \\
\text { also personal preference. }\end{array}$ \\
\hline 9 & I liked the vertical grip. Felt like I had more control of the M4. \\
\hline 10 & $\begin{array}{l}\text { Yes, forces you to put hand further out if positioned there which increases stability. Keeps you from } \\
\text { putting your hand in front of the barrel if you have a shorter barrel rifle. }\end{array}$ \\
\hline 11 & Yes. Easily controlled and maneuvered. \\
\hline 12 & $\begin{array}{l}\text { I believe the weapon configuration is acceptable for an assault weapon because it allows quick target } \\
\text { acquisition during CQB operations, stability without holding heat shields. }\end{array}$ \\
\hline 13 & $\begin{array}{l}\text { Yes, fatigue onset is greatly reduced with vertical handgrip. Able to react to new targets more } \\
\text { efficiently. }\end{array}$ \\
\hline 14 & $\begin{array}{l}\text { Yes, the vertical grip is excellent for pulling the weapon into your shoulder. It also assists with } \\
\text { driving the weapon to the target when moving the weapon left and right. }\end{array}$ \\
\hline 15 & $\begin{array}{l}\text { Acceptable yes; however, I felt more comfortable without the vertical grip. I noticed that my wrist } \\
\text { would be canted and start cramping. }\end{array}$ \\
\hline 16 & $\begin{array}{l}\text { Yes, light weight and ease of use. The vertical grip may be useful to move your hand off of barrel } \\
\text { away from heat of sustainment fire. }\end{array}$ \\
\hline 17 & $\begin{array}{l}\text { Yes, I feel that the vertical hand grip allowed for easier manipulation of the weapon. It also helped } \\
\text { with holding it into your shoulder. }\end{array}$ \\
\hline 18 & $\begin{array}{l}\text { Yes, makes acquiring targets and engaging them easier. Balances your shooting platform more } \\
\text { comfortable. }\end{array}$ \\
\hline
\end{tabular}


Table 15 Summary of subjects' comments (direct quotes) from shooting the M4 carbine with and without a vertical grip (continued)

\begin{tabular}{|c|l|}
\hline $\begin{array}{c}\text { Subject } \\
\text { No. }\end{array}$ & \multicolumn{1}{c|}{ M4 Carbine without Vertical Grip } \\
\cline { 2 - 3 } & \multicolumn{1}{|c|}{ What changes would you recommend be made on the weapon configuration you just used? } \\
\hline 2 & More protection from the heat on the forward grip \\
\hline 3 & $\begin{array}{l}\text { Weapon sling ring needs to be in a better position, as not to dig into Soldiers' shoulder, } \\
\text { uncomfortable pressure. }\end{array}$ \\
\hline 4 & Use of tactical sling. Note: Used an M4 with vertical hand grip in Iraq for 2 combat deployments. \\
\hline 5 & $\begin{array}{l}\text { Extend the magazine well down further or add grip component to well. Redesign pistol grip to } \\
\text { reduce strain on upper wrist that is aligned with the thumb. }\end{array}$ \\
\hline 6 & $\begin{array}{l}\text { I need something to improve the butt stock/shoulder weld. It is very difficult to get the butt stock } \\
\text { to stay in place on my shoulder. Also, it is difficult to get the butt stock where I want it on my } \\
\text { shoulder from the low ready. }\end{array}$ \\
\hline 7 & I wouldn't recommend any changes at all. \\
\hline 8 & No comments \\
\hline 9 & None, personal preference. \\
\hline 10 & None that I can think of at the moment. \\
\hline 11 & Better heat shields. Weapon still gets hot even while wearing gloves. \\
\hline 12 & $\begin{array}{l}\text { None. } \\
\text { None. Buttstock stability improved by placing buttstock more towards center of the chest rather } \\
\text { than slip in and out of pocket of shoulder. }\end{array}$ \\
\hline 13 & $\begin{array}{l}\text { Weapon was difficult to keep from bouncing off of shoulder. Something to make weapon stack } \\
\text { stick to shoulder better would help, e.g., tacky rubber or more aggressive texture. }\end{array}$ \\
\hline 14 & Add a heat shield/hand guard system to the top rail. \\
\hline 15 & Make the weapon lighter, if possible. \\
\hline 16 & $\begin{array}{l}\text { Add some sort of grit to the fore end. Felt fatigued in the center of my back due to the way you } \\
\text { have to pull the weapon into shoulder for stability. }\end{array}$ \\
\hline 17 & $\begin{array}{l}\text { I think this weapon already has all of the bells and whistles, collapsible stock and 30 round } \\
\text { magazines. The only thing would be to put it full auto instead of burst. }\end{array}$ \\
\hline 18 & Add fore grip. \\
\hline
\end{tabular}


Table 15 Summary of subjects' comments (direct quotes) from shooting the M4 carbine with and without a vertical grip (continued)

\begin{tabular}{|c|c|}
\hline \multirow{2}{*}{$\begin{array}{l}\text { Subject } \\
\text { No. }\end{array}$} & M4 Carbine with Vertical Grip \\
\hline & What changes would you recommend be made on the weapon configuration you just used? \\
\hline 1 & $\begin{array}{l}\text { The pistol (vertical) grip should be able to have a quick release in case of the Soldier needs to get } \\
\text { rid of it. }\end{array}$ \\
\hline 2 & $\begin{array}{l}\text { Not sure at this time. Note: Did not use vertical hand grip when going out on patrols because did } \\
\text { not want weapon to get caught in seat belt and weapon mount was not configured for a M4 with a } \\
\text { hand grip. Also, kept weapon lighter to carry. }\end{array}$ \\
\hline 3 & Use of combat sling. \\
\hline 4 & $\begin{array}{l}\text { More ergonomic design to reduce fatigue, especially for pistol grip. Used vertical hand grip during } \\
\text { deployment in Egypt exclusively in training scenarios (weapon quals, reflexive drills) }\end{array}$ \\
\hline 5 & $\begin{array}{l}\text { Same comment as "without the grip". I need something that improves the way the butt stock sits in } \\
\text { my shoulder. Note: I used the vertical hand grip while patrolling in Iraq. But, I can't remember if I } \\
\text { ever qualified with it. }\end{array}$ \\
\hline 6 & $\begin{array}{l}\text { I don't necessarily enjoy using the CCO. I prefer using the iron sights. I like that the M-4 is } \\
\text { compact and the butt stock is adjustable, but I feel as though it takes me longer to get a good and } \\
\text { comfortable sight picture as a result of this. I'm sure that if I had more practice firing the M4, I } \\
\text { would probably feel just as comfortable with it as I am with the M16A1/A2. }\end{array}$ \\
\hline 7 & Keeping the grip further forward on the weapon. I use the vertical grip on my duty weapon (M4). \\
\hline 8 & $\begin{array}{l}\text { I would slant the forward grip to an angle to more of a } 45 \text { degree instead of a } 90 \text { degree. This } \\
\text { weapon configuration is part of my everyday carry for work. }\end{array}$ \\
\hline 9 & $\begin{array}{l}\text { Nothing at the moment. Note: My service weapon does not have a vertical grip. I have always shot } \\
\text { without one. If I had the choice of using a vertical grip. I would use one. }\end{array}$ \\
\hline 10 & $\begin{array}{l}\text { Doesn't need to be so long. Sometimes makes shooting in prone difficult. My current weapon is } \\
\text { the Bushmaster Carbon } 15 \text { with a hand grip. Being tall, the hand grip keeps me from extending my } \\
\text { arm past the barrel. }\end{array}$ \\
\hline 11 & $\begin{array}{l}\text { Moving the vertical grip out as far on the Picatinny rail as it will so. I use a vertical hand grip on } \\
\text { my service weapon. }\end{array}$ \\
\hline 12 & $\begin{array}{l}\text { During the employment of this configuration, I had a hard time trying to figure out if I should push } \\
\text { hand grip while slightly pulling back to shoulder with firing hand, vice versa or just maintaining a } \\
\text { neutral balance. In my experience including a tactical sling into the configuration makes all of the } \\
\text { difference because depending on how you use the sling, it will keep your weapon stock tight to } \\
\text { your shoulder while using your forward grip to push forwards toward target. Note: The IOTV } \\
\text { completely covers the nook of my shoulder and chest so the butt stock will not remain in place. } \\
\text { Also, I do not use the vertical hand grip on my service weapon because I employ an M203 G.L. } \\
\text { with my M4 rifle. }\end{array}$ \\
\hline 13 & $\begin{array}{l}\text { Buttstock needs to be upgraded to better stick to dig into shoulder pocket. Note: Service weapon } \\
\text { (M4) has a vertical hand grip. }\end{array}$ \\
\hline 14 & $\begin{array}{l}\text { Shorten the vertical grip and change the buttstock. Most of my issues were because the buttstock } \\
\text { slipping/sliding around. The vertical grip does assist in helping to eliminate this issue. I use a } \\
\text { shortened version of this vertical grip on my service weapon. }\end{array}$ \\
\hline 15 & Not sure. Yes, my SRT weapon does have a vertical hand grip. \\
\hline 16 & Magpul@ ergo grip instead of vertical grip. I have shot with a vertical grip on my personal M4. \\
\hline 17 & Again, improvements made were a hand grip, but the weapon was still easy to use. \\
\hline 18 & None. Note: yes my SRT service weapon has vertical grip on MK-18. \\
\hline
\end{tabular}




\section{Discussion}

None of the shooting performance-dependent measures shown in Tables 6-12 (mean target hit rate, mean radial error, mean time of shot, or mean time of hit) for the reflexive position (near targets) and aimed position (far targets) of firing was significantly different for the M4 carbine with and without a vertical grip. The standard deviations of each of the dependent measures were small, indicating no gross data points that could be considered outliers. This shows that the shooting performance of subjects using the M4 carbine with and without a vertical grip for either reflexive (near) or aimed (far) targets was not affected by the weapon's configuration. We propose that as long as basic rifle marksmanship is practiced during the shooting scenarios, the weapon's configuration has no effect on the overall outcome of subjects' shooting performance.

Table 14 shows that subjects subjectively rated all characteristics (except for "Ease of operating safety lever”) better, but 4 characteristics for the M4 carbine with the vertical grip were rated significantly better than the M4 carbine without the vertical grip. These 4 characteristics were 1 ) ease of holding the weapon unsupported, 2) ease of scanning for targets, 3) ease of assuming a good firing position, and 4) ease of obtaining an accurate first shot. A review of the comments from the subjects showed that most of them had positive comments on the 4 characteristics mentioned above. Even though the statistical analyses of all aspects of the objective shooting performance-dependent measures (mean target hit rate, mean radial error, mean time to shot, and mean time to hit) showed no significant differences between the M4 with and without the vertical grip, subjects may have perceived that their shooting performance was better and hence may have improved their perceived confidence in the M4 carbine configuration with the vertical grip. Since this was the case, then perhaps a future follow-on shooting study should be conducted with more emphasis on obtaining the subjective ratings of the Soldiers' experiences when firing with the vertical grip. The follow-on study could be designed to allow more range of personal preference on the configuration of the weapon. This follow-on study may then show if there is any strong correlation between the subjective ratings and objective shooting performance data.

From Table 15, some subjects made negative comments about the use of the M4 carbine with the vertical grip (e.g., “did not want weapon to get caught in seat belt”, “makes shooting in prone difficult"). In contrast, some subjects made positive comments when they used the M4 carbine with the vertical grip (e.g., "was easy far more to maintain a steady aim”, "Point and shoot” was easier"). Let's analyze the sample comment of "makes shooting in the prone difficult" with the vertical grip on an M4 carbine. Granted, some subjects said that it makes the weapon stable when firing (when standing), but when shooting in the prone, it is difficult. This is because in the prone, the vertical grip would have to be rested on a surface to fire properly. But because the vertical grip extends beyond the standard forward handgrip area, shooting in the prone would be difficult because the shooter would need more clearance to be able to get the proper stock weld 
on the buttstock. The modification of a weapon system should be investigated based on not only the shooting aspect, but also the overall performance of the system with the user as a whole. Issues such as how the weapon is carried by the Soldier, compatibility with his equipment, compatibility with tactical vehicles, and the ease or difficulty of having to adjust to different tactical situations should all be investigated.

Despite the positive comments (listed in Table 15) regarding the vertical grip with respect to handling, scanning, repeatable and reliable firing posture, and perceived first shot accuracy, subjects performed equally well across weapon conditions (i.e., with or without the forward grip). This may be due in part to the stable position assumed by most subjects with respect to the supporting hand, where they would often brace it against the magazine well (as shown clearly in Fig. 5) or otherwise securely grip the forward rail/handguard system during weapon firing. Operationally, the addition of the forward vertical grip is often required when affixing other weapon accessories, such as flashlights and pointer/illuminators (e.g., AN/PEQ-series infrared illuminators), where surface area on or around the forward rail/handguard system is limited. Attaching the forward vertical grip in such cases allows for secure bracing using the supporting hand where otherwise the space to do so would be limited.

Another common observation noticed by the experimenters that occurred during data collection was the nontraditional use of the vertical grip as a firing support position for the off-hand (e.g., Fig. 7). Though these techniques - essentially bracing the fore end of the weapon in a less stable manner than securely grasping the vertical grip (as shown in Fig. 6) —are not necessarily commonplace, they lend support to the notion that the specific method with which a shooter braces/supports the forward weapon system components is perhaps less important than the ultimate stability imparted upon shooter-weapon system dynamics during firing. Specific technique may be of greater importance to higher recoil systems that feature increased force and motion relative to the moderate recoil experienced when firing the M4 carbine using standard 5.56-mm M855/M855A1 ammunition. 


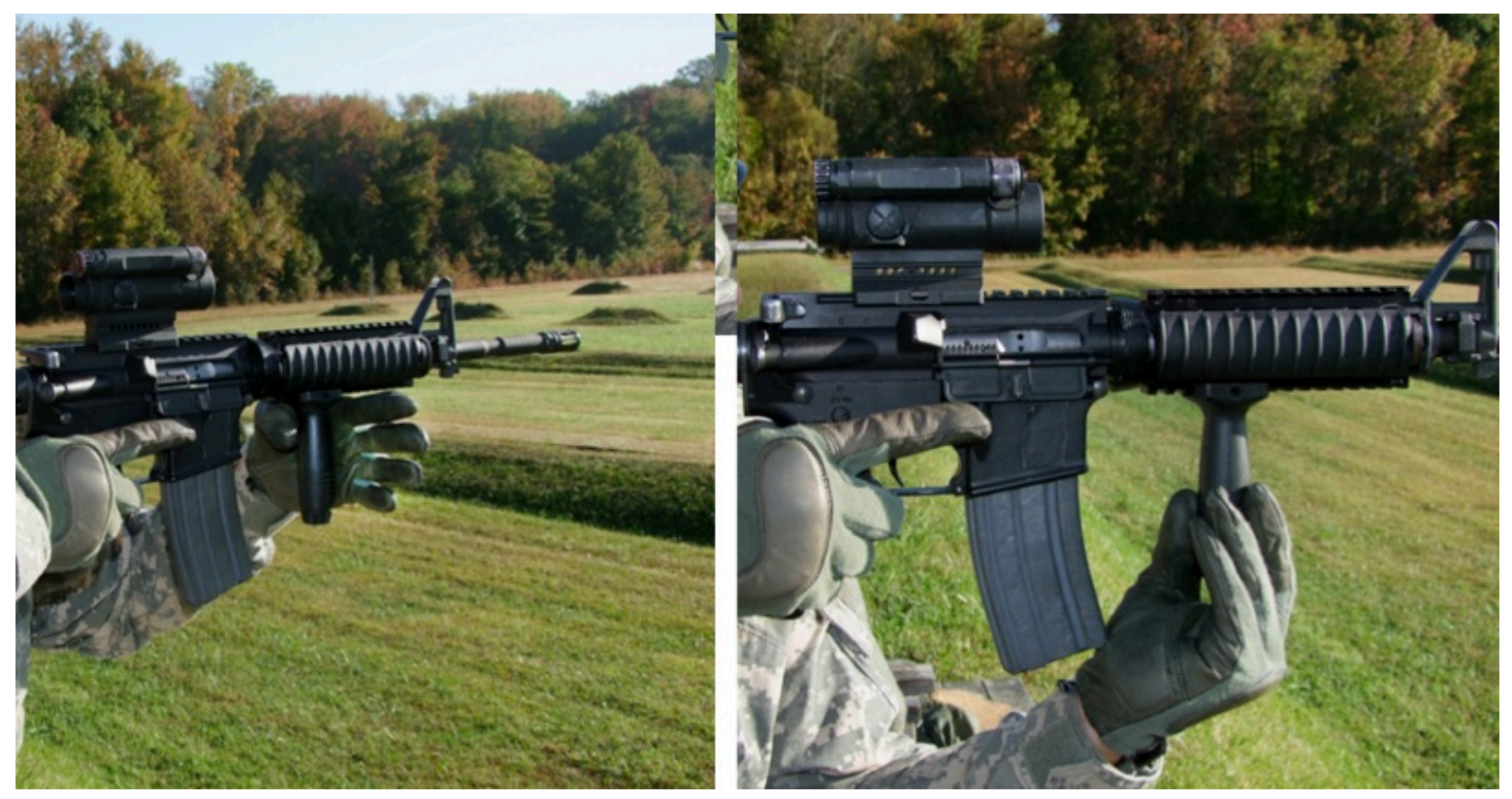

Fig. 7 Examples of bracing, rather than securely grasping, the weapon using the forward vertical grip

\section{Conclusion}

Subjects preferred the use of the M4 with the vertical grip, but its use did not translate into any shooting performance improvement over the M4 without a vertical grip.

\section{Recommendations}

Since there were no significant differences for the objective measures between the M4 carbine with and without a vertical grip, no recommendation can be made for or against the use of an M4 carbine with a vertical grip. However, the 4 characteristics that were rated significantly better subjectively for the M4 carbine with the vertical grip show the subjects' perceived confidence in their shooting performance may have been positively affected. These 4 characteristics were 1 ) ease of holding the weapon unsupported; 2) ease of scanning for targets; 3) ease of assuming a good firing position; and 4) ease of obtaining an accurate first shot. Consequently, perhaps the use of a vertical grip should be left at the discretion of each user. A follow-on study could be conducted to quantify the subjective ratings as Soldiers fire the M4 carbine with and without a vertical grip. Soldiers should be allowed to configure the weapon they think would provide the best comfort, handling, and usability in order to improve their shooting performance. 
When subjects were asked about the acceptability of the M4 with the vertical grip as an assault weapon, 6 out of 18 subjects stated that they felt the vertical grip improved their stability. In order to quantify the improved stability claim that subjects stated, perhaps a study could be designed to investigate the stability of the M4 carbine with the vertical grip compared to one without a vertical grip. An optical recording device, mounted on the barrel, that measures aiming error could be attached to the weapon's muzzle. The device could then quantify aiming error as subjects aim and shoot at targets. This could lead to an investigation of aiming error as another measure of shooting performance in addition to the number of targets hit, time to shot, time to hit, and $\mathrm{x}$ and $\mathrm{y}$ coordinates of projectile impacts.

Six of the 18 subjects also commented on weapon control with the vertical grip attached. Most of them stated that the vertical grip allowed them to easily get on target, easily point and shoot the weapon, and naturally control the weapon. Comments like these were likely made because the vertical grip allowed users to completely wrap their fingers around the vertical grip as opposed to having to hold the forward handgrip only halfway because of its bigger diameter.

Three out of 18 Soldiers commented that the vertical grip afforded them the ability to tuck in the buttstock tighter into the shoulder. This was understandable since the forward handgrip allowed them to apply more pressure with their non-firing hand and pull the forward part of the weapon toward their shoulder. This then allowed for a more stable shooting posture than without a vertical grip. It would be more difficult to pull the buttstock toward your shoulder using the forward handgrip since it does not allow one to apply a perpendicular force like the vertical grip does.

An interesting comment by 3 of the 18 subjects was their suggestion of angling the forward handgrip instead of having it perpendicular to the longitudinal axis of the weapon. One of the subjects mentioned the use of a Magpul ergo grip. The Magpul brand forward grip is commercially available and is angled at about $45^{\circ}$ or less from the horizontal. It is not known whether this angled grip does or does not help in shooting performance. Perhaps a study comparing shooting performance of a vertical forward handgrip compared to an angled forward handgrip merits further investigation. If such a study is undertaken, then it is recommended that the baseline condition using the standard M4 carbine with the forward handgrip should also be included.

A subject mentioned that he would like a quick-release feature of the forward vertical grip in case he had to quickly remove it for some reason (to get into the prone firing position if under immediate fire and wanting to return fire without exposing much of his body). Another subject mentioned that getting in the prone and shooting was difficult. The length of the forward vertical grip would make shooting in the prone difficult since typically the forward part of the weapon is rested on a structure for stability. Also, with the forward vertical grip resting on a structure, it will raise the profile of the shooter and expose more of his silhouette. If a quick-release feature was included in a forward vertical grip, then the problem of getting in the prone firing position 
would be eliminated since the forward vertical grip could easily be removed before the user got in the prone position. It is recommended that manufacturers of forward vertical grips consider a quick-release feature that would allow users to immediately remove the forward vertical grip should the need arise.

Four of the 18 subjects said that they had difficulty maintaining the buttstock of the weapon on their shoulder. This was mainly due to the buttstock material being made of hard plastic and interacting with their Improved Outer Tactical Vest (IOTV). The IOTV material is made of nylon backed by hard material underneath. When the hard plastic buttstock touches the nylon material of the IOTV, there is hardly any friction to hold the buttstock in place on the pocket of the shoulder area. This is a common compatibility problem with the M4 carbine and IOTV in general. Suggestions could be made to improve the contact between the buttstock and the IOTV surface, such as placing a sticky rubber material over the buttstock.

Two of the 18 subjects mentioned the need for a sling on the weapons they used. None of the weapons used in this study had a sling. One of the issues of using a sling is that users in the field use all different types of slings, most of which are commercial-off-the-shelf slings. There are so many different types of sling designs on the market (e.g., single-point sling, 2-point sling, 3-point sling); the current standard-issue sling for the M4 carbine is simply a black sling about 1.25 inches wide with 2 buckles at each end for limited adjustability. Most users prefer using a sling that they can customize. Slings were not used on the weapons for this study so that all subjects held the weapon similarly, as some subjects may or may not have used the sling during firing. Not using the sling standardized one weapon variable condition for this study. Perhaps in future studies slings should be considered if users insist on having them or have stated a need and have been trained to use them. A survey of subjects on their experience or training in using a sling could be conducted. Depending on the results of such a survey, a decision could be made whether to use a sling or not for future studies. Even if a sling is used, the question of which sling to use must be decided.

This study demonstrated that the use or non-use of a vertical grip does not affect shooting performance. The US Army Armament, Research, Development and Engineering Center of Picatinny Arsenal has been investigating the application of "powered rail" to be used on future weapons so that any device needing power is simply attached to the powered rail rather than having individual batteries for separate battery-powered devices. The use of a vertical grip will actually afford the weapon more space to attach additional battery-powered devices that improve shooting performance, target acquisition, and target engagement.

The overall use and impact of any addition or modification to a weapon system should be investigated as to its effect on the weapon-user interaction. The modification's effect on user acceptance, Soldier equipment compatibility, effect of weight on weapon system, reliability, and portability should be examined before employing any modifications. This should be a separate subtest in the overall future study should modifications be made to any weapon system. 


\section{References}

Gordon CC, Churchill T, Clauser CE, Bradtmiller B, McConville JT, Tebbetts RA, Walker RA. 1988 anthropometric survey of US Army personnel: methods and summary statistics. Natick (MA): Army Natick Laboratories (US); 1989. Report No.: Natick/TR-89/044.

US Army. Rifle marksmanship M16A1, M16A2/3, M16A4, and M4 carbine. Washington (DC): Headquarters, Department of the Army; 2003. Field Manual No.: 3-22.9. 
INTENTIONALLY LEFT BLANK. 
Appendix A. Demographic and Anthropometric Data Sheets

This appendix appears in its original form, without editorial change. 
Test participant Number

Age $\operatorname{sex}$ Rank Time in service years months

Primary MOS Secondary MOS

Time in current MOS

1. When was the last time you qualified with an assault rifle? Month Year Weapon (e.g. M4, M16)

2. What is your current level of qualification as rifleman? Marksman Sharpshooter

Expert

3. Are you a left handed or right handed shooter? (Check one)

4 Do you use your __ left eye or __ right eye to aim a weapon? (Check one)

5. Do you wear glasses or contact lenses when you shoot? Yes No (Check one)

6. Do you have any unusual difficulties seeing objects during daytime? Yes No (Check one) If yes, what difficulties do you experience?

7. Have you used any optical devices or thermal sights(i.e., telescopes, binoculars)? used. Yes No (Check one). If yes, list the type of device(s)

8. Do you have any experience with the following equipment? Please check all that apply.

ACOG

M68

M145 MG0

AN/PAS-13 TWS 


\section{Anthropometric Measurements}

Test participant number

Stature, cm

Weight, kg 
INTENTIONALLY LEFT BLANK. 


\section{Appendix B. Informed Consent Form}

This appendix appears in its original form, without editorial change. 


\section{Informed Consent Form}

Army Research Laboratory, Human Research \& Engineering Directorate

Aberdeen Proving Ground, MD 21005

Title of Project: Quantifying Soldier Shooting Performance of the M4 Carbine with and without a Vertical Grip .

Project Number: ARL 12-005

Sponsor: Army Research Laboratory

Principal Investigator: Samson V Ortega, Jr.

Army Research Laboratory

Human Research \& Engineering Directorate

RDRL-HRS-B, Bldg. 459

Aberdeen Proving Ground, MD 21005

(410) 278-5990; sortega@arl.army.mil

Associate Investigator: William Harper

Army Research Laboratory

Human Research \& Engineering Directorate

RDRL-HRS-B, Bldg. 459

Aberdeen Proving Ground, MD 21005

(410) 278-5955; bharper@arl.army.mil

Associate Investigator: Frank Morelli

Army Research Laboratory

Human Research \& Engineering Directorate

RDRL-HRS-B, Bldg. 459

Aberdeen Proving Ground, MD 21005

(410) 278-8824; frank.morelli@us.army.mil

You are being asked to join a research study. This consent form explains the research study and your part in it. Please read this form carefully before you decide to take part. You can take as much time as you need. Please ask questions at any time about anything you do not understand. You are a volunteer. If you join the study, you can change your mind later. You can decide not to take part now or you can quit at any time later on.

\section{Purpose of the Study:}

The purpose of this study is to quantify Soldier shooting performance of the M4 carbine with and without a vertical grip.

\section{Procedures to be followed:}

You are being asked to participate in a study to investigate Soldier shooting performance of the M4 
carbine with and without the use of a vertical grip. This study will take place at the HRED's firing range Aberdeen Proving Ground, MD 21005. This study will last approximately 8 hours per day for the next 5 days. Your work schedule will be from approximately 0800 to 1600 . In this study you will asked to shoot an M4 carbine either with or without a vertical grip at targets that will be presented at various ranges and target exposure times. You will be asked to aim as close as you can to a mark on the center mass of the Esilhouette target since the $\mathrm{X}$ and $\mathrm{Y}$ coordinates of the projectile impacts will be collected. In addition, the number of shots fired, number of targets hit and time to first shot will also be gathered. You will be asked to complete a questionnaire relating to shooting performance issues of the weapon configuration you just used. The next day you will then be assigned the weapon configuration that you did not shoot with the day before (M4 carbine with or without the vertical grip). The same procedure will be followed while you use this weapon configuration.

\section{Anthropometric Measurements}

For this study, you will have stature and weight measurements taken. A researcher will take these measurements on you. It should take approximately 3 minutes to take these various measurements.

\section{Training}

You will be assigned an M4 with or without a vertical grip. You will then zero with that weapon configuration. Once you are done zeroing with the assigned weapon, for training, you will fire at Esilhouette targets presented at various ranges with a constant target exposure time while firing in the reflexive mode standing unsupported. You will conduct at least three training trials with the assigned weapon configuration.

After firing for record, you will repeat this process with the same weapon while firing in the aimed firing while standing unsupported.

The following day, you will change weapon configurations and repeat this training sequence.

\section{Experimental Conditions}

There will be two experimental conditions for the weapons in this study, an M4 carbine with a vertical grip and an M4 carbine without a vertical grip. You will also be firing the weapon configurations in two modes: reflexive firing while standing unsupported and aimed firing while standing unsupported. You will shoot with a different weapon configuration (experimental condition) each day for about 5 days.

\section{Testing Sequence}

After a 5-minute break from training, you will proceed to the data collection phase.

With the same weapon configuration, you will fire at various E-silhouette targets presented at various ranges with a constant target exposure time while firing in the reflexive mode standing unsupported mode. The number of rounds fired, number of targets hit, time to first shot, $\mathrm{X}$ and $\mathrm{Y}$ coordinates of the projectile impacts will be collected. You will conduct three record fire trials using the same weapon configuration and mode of fire. You will then proceed to firing the same weapon configuration in the aimed firing mode while standing unsupported.

At the completion of these tasks, you will be asked to complete a questionnaire on your experience with the weapon configuration you just fired. Your opinion on the firing characteristics of the weapon configuration will be asked. The data collected in this study will be used for research purposes only. 
The following day, you will change weapon configurations and repeat this testing sequence.

Thank you for your participation, and please feel free to ask the experimenter any questions you may have.

\section{Discomforts and Risks:}

The risks are minimal. The risks associated with your participation in this study will not be more than may be encountered during your normal tour of military duty while performing your specific MOS. The M4 carbines are standard issue weapons.

\section{Benefits:}

There are no direct benefits to you for your participation in this study. Your participation in this study will help quantify shooting performance of the M4 carbine with and without a vertical grip when it is fired from the reflexive firing position or aimed firing standing unsupported positions. This information could be used to clarify and either support or negate the use of a vertical grip on a shoulder fired weapon.

Duration: It will take approximately 8 hours of your time over 5 days to take part in this study.

\section{Confidentiality:}

Your participation in this research is confidential. The data will be stored and secured at Aberdeen Proving Ground, Building 459 in a locked file cabinet. Data with no identifying information will be transferred to a password-protected computer for data analysis. After the data is put in the computer file, the paper copies of the data will be shredded. This consent form will be sent to Army Research Laboratory's Institution Review Board, where it will be retained for a minimum of three years.

In the event of a publication or presentation resulting from the research, no personally identifiable information will be shared. Publication of the results of this study in a journal or technical report or presentation at a meeting will not reveal personally identifiable information. No personally identifiable information will be shared with anyone outside the research staff. Officials of the U. S. Army Human Research Protections Office and the Army Research Laboratory's Institutional Review Board may inspect the records obtained in this study to insure compliance with laws and regulations covering experiments using human subjects.

\section{Consequences of withdrawal.}

If you ask to stop the study for any reason, there will be no negative consequences to you.

\section{Contact Information for Additional Questions:}

You have the right obtain answers to any questions you might have about this research both while you take part in the study and after you leave the research site. Please contact anyone listed at the top of the 
first page of this consent form for more information about this study. You may also contact the Chairperson of the Human Research \& Engineering Directorate, Institution Review Board, at (410) 2785992 with questions, complaints, or concerns about this research, or if you feel this study has harmed you. The Chairperson can also answer questions about your rights as a research participant. You may also call this number if you cannot reach the research team or wish to talk to someone else.

\section{Voluntary Participation:}

Your decision to be in this research is voluntary. You can stop at any time. You do not have to answer any questions you do not want to answer. Refusal to take part in or withdrawing from this study will involve no penalty or loss of benefits you would receive by staying in it.

Military personnel cannot be punished under the Uniform Code of Military Justice for choosing not to take part in or withdrawing from this study, and cannot receive administrative sanctions for choosing not to participate.

You must be 18 years of age or older to take part in this research study. If you agree to take part in this research study based on the information outlined above, please sign your name and the date below.

You will be given a copy of this consent form for your records.

This consent form is approved from

Do not sign after the expiration date of 15 December 2013

Participant Signature

Person Obtaining Consent
Date

Date 
INTENTIONALLY LEFT BLANK. 


\section{Appendix C. Posttest Questionnaire}

This appendix appears in its original form, without editorial change. 


\section{M4 Carbine Vertical Grip Shooting Performance Questionnaire}

Test Partic ipant Number

Date

Condition: M4 with vertical grip

: M4 without vertic al grip

You have just completed firing in one of the M4 carbine weapon configurations. We would like you to answer specific questions and rate characteristics of the weapon configuration you used. Based on your shooting experience, answer the questions by filling in the circ le that best represents your opinion for each rating. Mark only one circle per rating.

\begin{tabular}{|l|c|c|c|c|c|}
\hline & Excellent & Good & Acceptable & Marginal & Poor \\
\hline 1. Ease of holding weapon unsupported & $\mathrm{O}$ & $\mathrm{O}$ & $\mathrm{O}$ & $\mathrm{O}$ & $\mathrm{O}$ \\
\hline 2. Ease of holding weapon steady & $\mathrm{O}$ & $\mathrm{O}$ & $\mathrm{O}$ & $\mathrm{O}$ & $\mathrm{O}$ \\
\hline 3. Ease of pulling weapon to shoulder & $\mathrm{O}$ & $\mathrm{O}$ & $\mathrm{O}$ & $\mathrm{O}$ & $\mathrm{O}$ \\
\hline 4. Ease of slewing to target & $\mathrm{O}$ & $\mathrm{O}$ & $\mathrm{O}$ & $\mathrm{O}$ & $\mathrm{O}$ \\
\hline 5. Ea se of operating safety lever & $\mathrm{O}$ & $\mathrm{O}$ & $\mathrm{O}$ & $\mathrm{O}$ & $\mathrm{O}$ \\
\hline 6. Ease of obtaining a good sight picture & $\mathrm{O}$ & $\mathrm{O}$ & $\mathrm{O}$ & $\mathrm{O}$ & $\mathrm{O}$ \\
\hline 7. Ease of maintaining a good sight picture & $\mathrm{O}$ & $\mathrm{O}$ & $\mathrm{O}$ & $\mathrm{O}$ & $\mathrm{O}$ \\
\hline 8. Ease of bringing weapon up to cheek & $\mathrm{O}$ & $\mathrm{O}$ & $\mathrm{O}$ & $\mathrm{O}$ & $\mathrm{O}$ \\
\hline 9. Ease of holding cheek to stock weld & $\mathrm{O}$ & $\mathrm{O}$ & $\mathrm{O}$ & $\mathrm{O}$ & $\mathrm{O}$ \\
\hline 10. Ease of scanning for targets & $\mathrm{O}$ & $\mathrm{O}$ & $\mathrm{O}$ & $\mathrm{O}$ & $\mathrm{O}$ \\
\hline 11. Ease of a ssuming a good fining position & $\mathrm{O}$ & $\mathrm{O}$ & $\mathrm{O}$ & $\mathrm{O}$ & $\mathrm{O}$ \\
\hline 12. Ease of obtaining an accurate first shot & $\mathrm{O}$ & $\mathrm{O}$ & $\mathrm{O}$ & $\mathrm{O}$ & $\mathrm{O}$ \\
\hline 13. Ease of shooting at stationary targets & $\mathrm{O}$ & $\mathrm{O}$ & $\mathrm{O}$ & $\mathrm{O}$ & $\mathrm{O}$ \\
\hline 14. Ease of loading a magazine & $\mathrm{O}$ & $\mathrm{O}$ & $\mathrm{O}$ & $\mathrm{O}$ & $\mathrm{O}$ \\
\hline 15. Weight of weapon & $\mathrm{O}$ & $\mathrm{O}$ & $\mathrm{O}$ & $\mathrm{O}$ & $\mathrm{O}$ \\
\hline 16. Balance of weapon & $\mathrm{O}$ & $\mathrm{O}$ & $\mathrm{O}$ & $\mathrm{O}$ & $\mathrm{O}$ \\
\hline 17. Weapon stability duning firing & $\mathrm{O}$ & $\mathrm{O}$ & $\mathrm{O}$ & $\mathrm{O}$ & $\mathrm{O}$ \\
\hline 18. Fatigue induced by using this weapon & $\mathrm{O}$ & $\mathrm{O}$ & $\mathrm{O}$ & $\mathrm{O}$ & $\mathrm{O}$ \\
\hline
\end{tabular}

Do you feel that use of the weapon configuration you just experienced is acceptable for an assault weapon? Why?

What changes would you recommend be made on the weapon configuration you just used? 


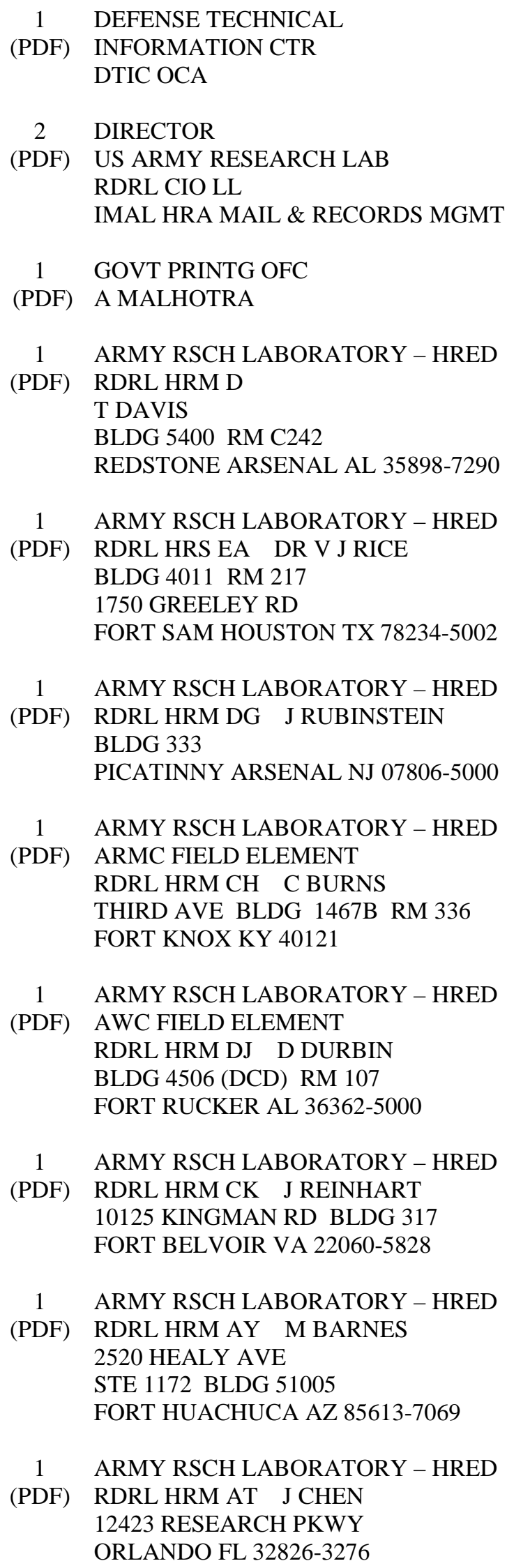

1 ARMY RSCH LABORATORY - HRED

(PDF) RDRL HRM AP D UNGVARSKY

POPE HALL BLDG 470

BCBL 806 HARRISON DR

FORT LEAVENWORTH KS 66027-2302
1 ARMY RSCH LAB - HRED
(PDF) HUMAN SYSTEMS
INTEGRATION ENGR
TACOM FIELD ELEMENT
RDRL HRM CU P MUNYA
6501 E 11 MILE RD
MS 284 BLDG 200A
WARREN MI 48397-5000

1 ARMY RSCH LABORATORY - HRED

(PDF) FIRES CTR OF EXCELLENCE

FIELD ELEMENT

RDRL HRM AF C HERNANDEZ

3040 NW AUSTIN RD RM 221

FORT SILL OK 73503-9043

1 ARMY RSCH LABORATORY - HRED

(PDF) RDRL HRM AV W CULBERTSON

91012 STATION AVE

FORT HOOD TX 76544-5073

1 ARMY RSCH LABORATORY - HRED

(PDF) RDRL HRM DE A MARES 1733 PLEASONTON RD BOX 3

FORT BLISS TX 79916-6816

\author{
8 ARMY RSCH LABORATORY - HRED \\ (PDF) SIMULATION \& TRAINING \\ TECHNOLOGY CENTER \\ RDRL HRT COL G LAASE \\ RDRL HRT I MARTINEZ \\ RDRL HRT T R SOTTILARE \\ RDRL HRT B N FINKELSTEIN \\ RDRL HRT G A RODRIGUEZ \\ RDRL HRT I J HART \\ RDRL HRT M C METEVIER \\ RDRL HRT S B PETTIT \\ 12423 RESEARCH PARKWAY \\ ORLANDO FL 32826
}

1 ARMY RSCH LABORATORY - HRED

(PDF) HQ USASOC RDRL HRM CN R SPENCER BLDG E2929 DESERT STORM DRIVE FORT BRAGG NC 28310

$1 \quad$ ARMY G1

(PDF) DAPE MR B KNAPP 300 ARMY PENTAGON RM 2C489 WASHINGTON DC 20310-0300 


\section{ABERDEEN PROVING GROUND}

14 DIR USARL

(PDF) RDRL HR

L ALLENDER

P FRANASZCZUK

RDRL HRM

P SAVAGE-KNEPSHIELD

RDRL HRM AL

C PAULILLO

RDRL HRM B

J GRYNOVICKI

RDRL HRM C

L GARRETT

RDRL HRS

J LOCKETT

RDRL HRS B

W HARPER

M LAFIANDRA

F MORELLI

S ORTEGA

RDRL HRS C

K MCDOWELL

RDRL HRS D

A SCHARINE

RDRL HRS E

D HEADLEY 